NBER WORKING PAPER SERIES

\title{
AN EVALUATION OF THE SWEDISH ACTIVE LABOR MARKET POLICY: NEW AND RECEIVED WISDOM
}

Anders Forslund

Alan B. Krueger

Working Paper No. 4802

\section{NATIONAL BUREAU OF ECONOMIC RESEARCH 1050 Massachusetts Avenue Cambridge, MA 02138 July 1994}

We are grateful to Per-Anders Edin and Bertil Holmlund for providing us with their county-level data set, and to Jörn-Steffen Pischke for providing us with data on Germany. We are also grateful to Anders Björklund, Per-Anders Edin, Richard Freeman, Bertil Holmlund, Lawrence Katz, Birgitta Swedenborg, and two reviewers for helpful comments. Naturally, we are responsible for any errors. This paper is part of NBER's research program in Labor Studies. Any opinions expressed are those of the authors and not those of the National Bureau of Economic Research. 
NBER Working Paper \#4802

July 1994

\title{
AN EVALUATION OF THE SWEDISH \\ ACTIVE LABOR MARKET POLICY: NEW AND RECEIVED WISDOM
}

\begin{abstract}
About 3\% of GNP is spent on government labor market programs in Sweden, compared to $2 \%$ in Germany and less than $0.5 \%$ in the U.S. In Sweden these programs include extensive job training, public sector relief work, recruitment subsidies, youth programs, mobility bonuses, and unemployment benefits. Using county-level data, we provide new evidence that public relief workers displace other workers, especially in the construction sector. Our review of the previous literature suggests that job training programs have small effects on wages and re-employment in Sweden, but precise inferences are difficult because of small sample sizes. We also investigate alternative reasons for the stability of the Beveridge Curve in Sweden, and compare regional evolutions of employment and unemployment in Sweden and the U.S. Lastly, we present crosscountry analysis for 1993 which, contrary to studies that use earlier data, shows that the extent of a country's active labor market programs is positively associated with the national unemployment rate.
\end{abstract}

Anders Forslund Department of Economics Uppsala University Box 513 S-751 20 Uppsala SWEDEN

\author{
Alan B. Krueger \\ Woodrow Wilson School \\ Princeton University \\ Princeton, NJ 08544 \\ and NBER
}


A visitor to Sweden is struck by the breadth and generosity of the labor market programs designed to limit the adverse effects of unemployment and expand employment. These programs include extensive job training, public sector relief work, recruitment subsidies, youth programs, mobility bonuses, and unemployment benefits. About $3 \%$ of GNP is spent on government labor market programs in Sweden, compared to $2 \%$ in Germany and less than $0.5 \%$ in the U.S. Several prominent observers have argued that the Swedish active labor market policies are responsible for the enviable unemployment experience of Sweden in the 1970s and 1980s. Layard, Nickell, and Jackman (1991, p. 473) go so far as to recommend that Sweden's "active labor market" programs serve as a model for other countries.

Figure 1 illustrates the Swedish unemployment rate semi-annually over the past 25 years. In the 1970s Sweden managed to maintain a low unemployment rate in the face of adverse oil price shocks that caused high unemployment and severe recessions in other industrialized countries. The unemployment rate in Sweden also remained low in the 1980s, while it trended upwards in other European countries. But a dramatic increase in the unemployment rate can be seen beginning in 1991. In July 1993, the U.S. Bureau of Labor Statistics calcuiated that the unemployment rate in Sweden reached $9.5 \%$, on a comparable basis to the U.S. unemployment concept. The U.S. rate at the same time was $6.8 \%$. For the first time in our lifetimes, the unemployment rate is higher in Sweden than in the U.S.1 The dramatic increase in unemployment in Sweden over the last two years casts doubt on the ability of the active labor market policies to blunt unemployment. At the same time, Sweden's history of low unemployment in the 1980s suggests that its labor market programs are not responsible for the 1991-93 downturn because the programs were 
substantially as generous in the 1980 s as in the early 1990 s.

The expense of the Swedish labor market programs may be justifiable if they produce benefits that exceed their costs. But the programs are a very expensive luxury if unemployment is high and if the programs are not effective at reducing unemployment or raising workers' skills. Given the rising level of unemployment, and other changes in the Swedish economy, an assessment of the effectiveness of the active labor market programs is especially timely.

As the pattem in Figure 1 suggests, macroeconomic indicators can give a possibly misleading indication of the efficacy of Sweden's labor market policies. In this paper we first review microeconometric evidence on two major active labor market programs in Sweden: public relief work and job training. One concern with public relief work is that such programs may displace other workers. We provide new evidence on "fiscal substitution" between public relief workers and other workers using county-level data. Specifically, we find evidence that public relief workers tend to displace private construction workers, which potentially limits the usefulness of public relief workers in reducing unemployment. The evidence is less clear on whether relief workers displace social welfare workers, which is another major sector in which relief workers are dispatched.

We also review previous evidence on the impact of job training programs on wages and re-employment probabilities. Due to small samples used in past studies, we find it very difficult to draw precise conclusions about the payoff to job training programs. In sum, our view of the microeconometric evidence is that one should remain agnostic about the 
effectiveness of job training and public relief programs in fighting unemployment.

We then attempt to reconcile the macroeconomic and international evidence -- which has been cited by many as support for the effectiveness of Sweden's active labor market programs - with the microeconometric evidence. We first provide evidence on the stability of the Beveridge Curve in the 1980s across counties in Sweden. One possible explanation for the stable Beveridge Curve is that rapid expansion of public sector employment has absorbed unemployed workers. We test this hypothesis with county-level data, and find little support for it. Second, we evaluate and update the cross-country unemployment tate analysis that Layard, Nickell and Jackman (1991) and others have performed. Using 1993 unemployment rate data, we find that greater spending on active labor market programs has a statistically insignificant and negative impact on unemployment. This finding is in sharp contrast with estimates for the 1980s. We also discuss several statistical limitations of the cross-country approach.

Finally, we present evidence on the reaction of employment and unemployment to regional shocks in Sweden. Specifically, we compare our findings on regional evolutions in Sweden to comparable results for the U.S. based on Blanchard and Katz (1992) and for the rest of Europe based on Decressin and Fatas (1993). These results suggest that Sweden's response to shocks is not particularly different from other countries', implying that Sweden's extensive labor market programs have not had a marked effect on regional labor market adjustments.

In our judgment, the evidence provides little support for the view that Sweden's past success in maintaining low unemployment stemmed primarily from its active labor market 
policies. On the other hand, the extensive labor market programs in Sweden are most likely not the cause of Sweden's current economic crisis. But our analysis of the evolution of unemployment suggests there is a real danger that the current high level of unemployment will persist for some time in the future. We conclude by considering policies that might help to improve the active labor market programs in the current economic climate.

\section{Overview of Programs}

As way of background, it should be noted that within the central blue-collar trade union (LO) in the early 1950s the question of how to combine full employment and price stability was discussed.' These diseussions led to the formulation of a program subsequently adopted by the Social Democrat government, based on a few comerstones, one of which being active labor market policies. First, LO would pursue a so called "solidaristic wage policy." In its original form this policy aimed at "equal pay for equal work," irrespective of the productivity levels of individual firms. Later, the policy principle (still under the same name) changed to one of unconditional wage equalization, or "equal pay for unequal work." Second, a strict stance of stabilization policies (primarily fiscal policy) was advocated in order to keep inflation low. One intended result of these two principles was shut-downs of low-productivity firms and layoffs. This motivated the third comerstone of the program, "active labor market policies," which were given the role of

\footnotetext{
'See Björklund (1990), Calmfors (1992), Flanagan (1987) and Stafford (1981) for excellent overviews of the labor market programs.
} 
transferring laid-off workers to expanding high-productivity fims.

Two points about the origin of the programs are worth noting: First, labor market policies are not considered a substitute for stabilization policies; second, labor market policies entail the so called "work principle" -- the aim of the programs is to accomplish a smooth and rapid transfer of laid-off workers to new employment rather than to provide welfare for the unemployed (i.e., "workfare" rather than welfare). Starting in the 1950s a system of manpower policy emerged based on active labor market policies. The present system can be described in terms of the following main ingredients: Unemployment insurance, measures to create employment, mobility enhancing measures, and measures targeted at the handicapped.

\section{Unemployment insurance}

Unemployment compensation is provided in two forms: First, there is a number of so called certified unemployment insurance (UI) funds, nun by the trade unions at the industry level, but to a large extent tax financed. In 1990 the coverage was slightly less than $80 \%$ of the labor force. Second, in addition to the UI system administered by the trade unions, since 1974 there is also a supplementary compensation system, cash benefit assistance (kontant arbetsmarknadsstöd, KAS), mainly designed for new entrants in the labor market, who usually are not members of any UI fund. UI fund members are entitled to compensation for 300 days (450 days for workers over age 55) whereas cash benefit assistance runs for 150 days ( 300 days for persons over age 55,450 days for persons over age 60). Daily compensation in the UI fund system is, within limits, fixed by the 
government regulating minimum and maximum levels at $80 \%$ ( $90 \%$ before July 5,1993$)$ of the recipient's normal income prior to unemployment. The level of compensation in cash benefit assistance is significantly lower than the average paid by the certified UI funds (in 1990174 versus 402 SEK per day). Carling, et al. (1994) find that the duration of unemployment spells for those on KAS benefits is only slightly shorter than those on UI benefits, in spite of the large benefit differential.

A special feature of the UI fund system is that fund coverage roughly coincides with wage bargaining units, as the funds are run by trade unions at the industry level. But the state grants to the UI funds are designed so that the marginal cost of extra unemployment among a fund's members is zero. ${ }^{2}$

A number of criteria, many of which are common to the UI funds and KAS, have to be met in order that a person be entitled to unemployment compensation. The two most important conditions are that recipients actively search for a job at a public employment office, and that an offer of "suitable" work must be accepted. Refusal to accept a job offer might lead to expulsion from compensation. To receive compensation from a UI fund, a "membership condition" and a "work condition" have to be met: the claimant must have paid membership fees to the UI fund for at least 12 months and must have been working for at least 75 days distributed over at least 4 months and must have been working for at least 75 days distributed over at least 4 months during the 12 months preceding the current unemployment spell. Participation in relief work as well as labor market retraining

\footnotetext{
${ }^{2}$ Changes in the UI system initiated in 1994 make membership compulsory, and add funds administered by the state.
} 
programs count as work in this respect.

Workers who do not meet the membership condition are entitled to KAS benefits if they meet either a work requirement of roughly the same type as for UI fund compensation. or an "education condition" The education condition is met if individuals have finished at least one year of school in excess of the nine compulsory years and searched for a job at a public employment office for at least 90 days.

As the duration of compensation is limited, the system also creates incentives to find a job before compensation runs out. ${ }^{3}$ This aspect has been stressed by Layard, Nickell and Jackman (1991) as a key factor behind the high observed Swedish real wage sensitivity to changes in unemployment. This, in turn, is a potential explanation for Sweden's favorable unemployment experiences during the 1980 s. It is important to note, however, that the system has recently changed. Since the late 1980 s participation in labor market programs qualifies for new periods of unemployment compensation, so in principle there is no limit on the amount of time a jobless person can spend outside the regular labor market by switching between training and unemployment compensation." There is some indirect evidence supporting this view: Axelsson and Löfgren (1991), studying the effects of retraining programs on income, found a significant positive effect on persons finishing training programs in 1981, whereas Regnér (1993) finds significant negative income effects for 1989 and 1990 program participants. A possible explanation for this difference is that

\footnotetext{
${ }^{3}$ When unemployment compensation runs out, individuals are eligible for social security, which offers significantly less generous compensation.

'The change in the system pertains to training programs; relief work has always been considered "work."
} 
in the latter period training qualified for unemployment compensation, so that the negative income effect reflects negative selection of program participants. Unfortunately, there is a lack of direct evidence (e.g. in the form of event histories) on the extent of a "circular flow" between unemployment and programs.

\section{Measures to create employment}

The principal measure to create employment has for a long time been public relief work. The primary stated aim is to counteract temporary downturns in labor demand. but relief jobs have also been targeted for groups with permanently high unemployment risks. Unemployed UI fund members who run out of unemployment compensation are in principle granted the right to a relief job. To qualify for a relief job one must be registered as an unemployed job applicant at a public employment office for a minimum number of days (about a week). The duration of relief jobs is normally capped at 6 months, and payment is according to collective agreement in the regular labor market. Relief workers are obliged to accept suitable job offers and can be expelled from relief jobs upon refusal. Relief work can be arranged by central or local governments, or (rarely) by the private sector. The typical relief job has traditionally been in building and road construction, but the emphasis has gradually changed to jobs in health and welfare. From the "workfare" point of view, relief work offers a "work test": if the employment office fails to find a suitable job for the applicant, it can test his willingness to work by offering a relief job.

Recruitmens subsidies, introduced in 1984, aim at facilitating employment for long-term 
unemployed and at creating permanent jobs in the local public sector for the long-term or partially unemployed. Subsidies normally amount to at most $60 \%$ of the total wage cost, and can be given for a maximum of 6 months.

Beginning in 1984, a variety of special "youth measures" have been used, and their use has intensified recently. The most recent form (introduced in July 1992) is called "youth practice," and is targeted at youths between 18 and 24 years old. Participants receive compensation roughly equal to unemployment benefits, and employers receive free labor. In addition to keeping participants out of unemployment, youth practice offers a work test of the same kind as relief work. The combination of youth practice and a deep recession are believed to have weakened significantly the incentives to hire youths.

Finally, since January 1993, unemployed persons can prolong their period of unemployment compensation by taking part in so called "labor market ventures". These last for at most 6 months and the participant receives income equivalent to unemployment compensation benefits. The employer, normally organizations, associations, or the public sector, gets free labor. To prevent crowding out, participants are supposed to perform duties which would otherwise not have been performed. As the number of participants has increased rapidly, this last condition might prove to pose problems: either participants do what they are supposed to do, in which case large numbers of people perform superfluous tasks, or, alternatively, crowding out will prove to be an important issue.

\section{Mobility enhancing measures}

The traditional mobility enhancing measure is employment service administration. 
The Swedish employment service is not limited to just a brokerage function -- another important function of it is to administer both unemployment insurance and selection to labor market programs. A distinguishing feature of the Swedish set-up regarding job brokerage is that the public employment service has had a legal monopoly position. Since the late 1970 s there has also been compulsory notification of vacancies through the public employment service."

Another mobility enhancing measure is "mobility grants/starting allowances." These grants are intended to facilitate geographical mobility by making moving an economically feasible alternative to unemployment in the home region. To qualify, one must be an unemployed person looking for a job in another region through the public unemployment service. Other, more strict criteria, such as belonging to certain "scarce" professions, have also been eligible from time to time.

Last, but not least, among the mobility enhancing measures is labor market retraining. The official aims are to help unemployed or persons facing unemployment risks to get a job, help persons with little education or obsolete education to attain a stronger position in the labor market and to facilitate for firms to find workers with adequate education. Labor market retraining comes in many different forms and is produced by a plethora of educational institutions on requisition by county-level authorities under the National Labor Market Board. Retraining eligibility is conditional on being unemployed or facing risk of unemployment and job-search through public employment service.

'One side benefit of the employment service's monopoly is that Swedish vacancy data are likely to be of high quality. 
Compensation on retraining programs is roughly equivalent to unemployment compensation.

Measures targeted for the disabled

There are of four basic measures targeted for the disabled: employment in community enterprises, public sheltered work, wage-subsidized employment, and vocational rehabilitation. A common feature of these measures is that their goal is to provide work for persons who, due to various disabilities, have difficulty obtaining employment in the regular labor market.

Quantitative Description

Table 1 summarizes the magnitude of key labor market programs in Sweden. the U.S., and Germany in various years. It is clear that Sweden spends much more on training and unemployment benefits per recipient than the U.S. Sweden's unemployment benefits are particularly generous by comparison to the U.S. ${ }^{6}$ Since workers who are in training programs also qualify for unemployment benefits, the total amount spent on workers undergoing training is of the same order of magnitude as the cost of tuition and room and board for a year at Harvard!?

Readers may be surprised to see, however, that $1 \%$ of the labor force is enrolled in public training programs in the U.S., which is slightly higher than the comparable figure for

${ }^{6}$ Sweden reduced its replacement ration by 10 percentage points in 1993, but benefits are still well above the U.S. level.

${ }^{7}$ As Richard Freeman has pointed out to us, this is also roughly equivalent to the cost of a year in a high-security prison. 
Sweden or Germany. This fact casts some doubt on the relative importance of "disguised unemployment" in labor market programs in Sweden. Even if one counted all of the Sweden's workers who are on training or public relief programs as unemployed, the unemployment rate in the 1980 s would have increased only by roughly $1 \%$. Thus, disguised unemployment cannot account for much of Sweden's historically low unemployment rate.

Although the proportion of the labor force receiving training is about the same, a much higher proportion of the unemployed undergo training in a given year in Sweden than in the U.S. In 1990 , government training participants were $62 \%$ as large as the number of unemployed workers. Moreover, a sizable proportion of the unemployed are also placed in public relief jobs in Sweden, a program for which there is no current analog in the U.S. Sweden devotes about $3 \%$ of GNP to labor market programs, which exceeds Germany (2.1\%) and the U.S. (.4\%). The increase in unemployment in Sweden in the past two years can be expected to cause a substantial increase in expenditures on labor market programs relative to GNP.

The changing importance of some of the main Swedish labor market programs is illustrated in Figure 2. The figure presents the proportion of the labor force that is directly involved in retraining, relief work, youth programs, or recruitment subsidies. A number of features stand out. First, relief work shows a clear counter-cyclical pattern. Second, the incidence of relief work has trended steadily downward in the 1980 s. Third, labor market retraining has not had the same cyclical variability as relief work, again except for the past few years. Fourth, the incidence of retraining gradually trended upward in the 1980s. As a 
result of these contrasting trends, the relative importance of retraining has grown in the 1980s and 1990s, while the relative importance of public relief work has declined. Sixth. there has been a dramatic increase in the prevalence of youth measures in recent years. Finally, the incidence of retraining and youth measures declined in 1993. This decline was partly a result of budgetary cutbacks and partly a result of greater participation in "labor market ventures."

\section{Theoretical Framework}

The Swedish labor market programs are diverse and extensive. It is important to consider each program in this overall context. For example, one must recognize that solidarity wage policy is likely to set a floor on wages; workers whose productivity level fall below this floor will find it difficult to obtain employment (sec Edin and Topel, 1994). Thus, the benefit of raising worker productivity through government training, say, is greater given the pre-existing wage rigidity. Similarly, wage subsidies to employers of low-wage employees will relax the constraint imposed by the solidarity policy, and thus could increase employment and enhance efficiency.

Moreover, the social cost of unemployment (or low productivity) is especially high in Sweden because unemployed workers qualify for generous transfer benefits, retraining, and public relief work. The high income tax also raises the social cost of unemployment or low productivity because tax revenue is foregone, which requires even higher tax rates (which in turn probably cause further labor supply distortions). And the fact that income taxes are progressive reduces the incentive to invest in human capital and search for better 
paying jobs. The adverse effects of these distortions could be reduced by effective government intervention to encourage training, mobility and employment.

If one takes the network of government programs as given, then the proper theoretical framework is to start from a situation with pre-existing distortions. As is well known, in this second-best setting government intervention could improve economic efficiency. In this framework, the benefits of successful labor market programs in Sweden are potentially greater than in the U.S., which may explain why the Swedish labor market programs are more extensive. But if the external environment changes, such as a reduction in marginal tax rates or unemployment benefits -- as has been the case in Sweden -- then this theoretical framework suggests that the social benefit of active labor market programs may be reduced.

One must also consider possible indirect effects of labor market programs on wage and employment outcomes. Theoretical bargaining models predict that labor market programs will exert upward pressure on wages. Aggregate time-series studies provide some empirical support for this prediction (Calmfors and Forslund (1991), Calmfors (1992) and Calmfors and Lang (1993)), although Edin, Holmlund, and Ostros's (1992) county-level analysis finds that labor market programs do not put upward pressure on wage bargains. It is thus possible that labor market programs cause higher wages and depress employment.

The total social costs and benefits of labor market programs must be compared to

Notice, however, that the government intervention does not necessarily have to involve government-provided training. For exarnple, the government could provide vouchers to individuals for private training, or the government could lower tuition costs through grants or loans. 
determine their optimal level. Rational design of policy would take into account the efficacy of labor market programs. If, on the margin, a kronor spent on retraining has a higher reward than a kronor spent on public relief work, then the retraining program shoul. receive a larger share of the available resources. Such cost-benefit comparisons are especially important given the rising expense of labor market programs, and the rising government budget deficit. Next we present an evaluation of the effectiveness of retrainin: programs and public relief works, drawing on the past literature and some new analysis.

\section{Displacement Effects of Public Relief Workers}

There was a large shift away from public relief work and toward job training in the 1980s. Nevertheless, over $10 \%$ of unemployed workers are placed on public relief jobs in 1990, and there is some discussion of expanding public relief in response to the current economic crisis. One potential drawback of public relief work is that public relief workers may displace private sector workers. There is an extensive literature on this topic in the U.S., beginning with Johnson and Tomola (1977). The theoretical argument is

straightforward: If the public sector provides relief workers to a local government agency or private sector firm, the local government or private firm will hire fewer workers than it otherwise would have hired.

Johnson and Tomola conclude that public sector employment programs used in the U.S. in 1966-75 tended to displace other workers, on net creating few additional jobs after 6 quarters. This conclusion is not without controversy. Borus and Hamermesh (1978) argued that Jobnson and Tomola's estimates are sensitive to their Almon lag specification, 
and nonrobust because of strong multicollinearity in their aggregate time-series data. Adams, et al. (1983) estimate displacement effects using a panel data set of annual observations on cities 1970-79. They find that public sector employment grants in 1978 and 1979 had a significant negative effect on payrolls, but not in 1977. In 1978, for example, 77 cents of every dollar in public sector employment grants was reflected in higher city payrolls. They attribute the finding of less of a displacement after 1977 to a redesign of the program, which tightened eligibility and required specific projects.

There has been only one previous study of displacement effects of public relief workers in Sweden. That study, by Gramlich and Ysander (1981), analyzes 14 annual time series observation from 1964 to 1977 . They focus on the two largest categories of public relief expenditures and employment: health and welfare workers and road construction workers. They estimate aggregate time series models, similar to Johnson and Tomola. Gramlich and Ysander find evidence of considerable displacement in road construction, but not in the health and welfare sector.

We investigate the displacement effects of public relief workers using annual data for 24 counties in Sweden over the period 1976-1991 for all construction workers, and over the period 1982-1990 for health and welfare workers. ${ }^{9}$ Specifically, we estimate employment equations of the form:

(1) $E_{i n}=\beta_{0}+\beta_{1} P R W_{i+1}+\beta_{2} W_{i n}+\beta_{3} X_{i n}+\mu_{i}+\tau_{1}+\varepsilon_{i n}$

The health and welfare workers series is shorter because of comparability problems with the county-level data in earlier years. 
where $E_{i t}$ is employment in county $i$ in year $t, P R W_{i n-1}$ is the total number of public relief workers in county $i$ in year $t-1, W_{t}$ is the log of the average real wage in county $i$ in year $t$ and $\mathrm{X}_{\mathrm{it}}$ is a vector of cyclical demand measures, such as the unemployment rate and vacancy rate. We also include unrestricted county fixed effects $\left(\mu_{i}\right)$ and unrestricted year effects $\left(\tau_{v}\right)$. Equation (1) is estimated separately for construction workers and for health and welfare workers. Relief workers should not be counted among the workers included in the dependent variable. Thus, fiscal substitution (i.e., displacement) will imply a negative coefficient on PRW, and complete fiscal substitution will imply a coefficient of -1.0 . We have also experimented with specifications using various lags of public relief workers, and with subsets of the covariates.

Results for construction workers are presented in Table 2. Each specification shows a negative and statistically significant coefficient on public relief workers, implying substantial displacement. Column 6 , which includes the largest set of covariates, indicates that .69 fewer private construction workers are employed for every additional public relief worker hired. The lowest estimate of displacement we find is -.36 , in specifications where we omit the year effects.

The results for health and welfare workers, reported in Table 3, are much less clear. The estimated displacement effect for health and welfare workers is not stable when different sets of covariates are included - it bounces from -2.26 to +.91 . Moreover, the standard errors are quite large, and the estimated effect is statistically insignificant in column 6, which includes the full set of covariates. Unfortunately, it is difficult to draw much of a conclusion on the extent of displacement for this group of workers. 
One potential problem with our estimates of displacement is that causality may run in the reverse direction. A prolonged downturn in the economy may stimulate the use of relief workers, thus generating a negative correlation between (lagged) relief workers and non-relief employment. We include cyclical demand measures (unemployment and vacancy rates) in the regressions to control for this possibility. Nevertheless, in a highly cyclical industry like construction, reverse causality may still be a concern. To explore this issue further we also estimated vector autoregressions for employment and relief workers in each sector. These estimates are reported in Table 4. The results indicate that lagged relief workers and lagged employment have a statistically significant effect in the employment equations, but lagged employment does not have a statistically significant effect in the relief worker equations. This finding suggests that causality does not run from employment to relief workers, but with our relatively short time period it is hard to draw furm conclusions from the vector autoregressions.

As a final check on the plausibility of our estimates, we estimated a vector autoregression for the durable manufacturing sector, an industry that is not directly affected by public relief workers. Since the durable manufacturing sector is highly cyclical, this industry provides a test of whether our previous results for the construction industry are spuriously reflecting cyclical patterns. The p-value for a joint test of three lags of the public relief variable in the employment equation for durable manufacturing workers is .11 $(F=2.03)$. The corresponding test for construction workers has a p-value of $.0000 \quad(F=9.07)$. These results suggest that the effect of relief workers on construction employment is not just spuriously reflecting the business cycle. 
To summarize, we find evidence of substantial displacement in the construction sector, but not in the health and welfare sector. This conclusion is very much like Gramlich and Ysander's, even though we analyze data for a more recent time period, exploit county-level data, and use different estimation methods.

\section{Job Training}

In view of the large amount of resources devoted to job retraining in Sweden, one would expect to find a vast microeconometric literature on the effectiveness of training programs. This is not the case. There have been only about one half dozen studies of the impact of job training on eamings with Swedish data. These studies use a variety of econometric models and data sets, and some studies use several estimation techniques. In Sweden as in the U.S., there is considerable uncerainty regarding the proper estimation method and specification for estimating the "treatment effect" of job training. But in Sweden problems of imprecise estimates are at least as imporant as model specification. In summarizing the literature, we report fixed effects estimates when multiple estimates were available. $^{10}$

Figure 3 summarizes the past literature on the impact of job training on eamings. The figure shows the estimated payoff to training as a proportion of eamings, with a bound of plus or minus two standard errors around the estimate. As a benchmark for these estimates, one should bear in mind that if job training raises participants' annual earnings by $3 \%$ for 20 years, then the present value of the payoff to the training roughly equals its

\footnotetext{
${ }^{10}$ See Björklund (1990) for a thoughtful summary of this literature.
} 
costs." Thus, one should hope that studies have enough precision to detect payoffs on the order of $3 \%$. Unfortunately, there is a wide range of estimates, and each of the estimates has a large standard error. Two of the estimates are significantly below .03 , and one is significantly above .03 .

To improve the precision of the estimates, we calculated the weighted average of the estimates, using. as weights the inverse sampling variance of the estimate. (We also calculated the standard error of the weighted-average estimate.) This is reported as study 6 . The weighted average payoff is slightly negative $(-.8 \%)$, but not statistically different from zero (std. error $=1.2 \%$ ). One could, however, reject the null hypothesis of a payoff on the order of $3 \%$ using the weighted average of the estimates. On the other hand, the arithmetic average of the estimated effects in the studies is positive, but it is not statistically different from zero or from $3 \%$.

These studies show that there is not enough support to reject the null hypothesis that training has no effect on participants' subsequent earnings. If we use the weighted average of the estimates, we would reject the null hypothesis that the payoff is on the order of $3 \%$, which is roughly the break even level for the training programs.

Individually, the studies of earnings lack sufficient power to reach a convincing conclusion on this critical issue. A high priority for researchers in Sweden should be the construction of data sets that permit precise estimates on the effect of job training programs.

\footnotetext{
"In making this calculation, we assume that the typical participant eams $\$ 15,000$ per year, that job training increases annual earnings permanently by $3 \%$, and that the individual works for 20 years. If we apply a real interest rate of $3 \%$ to future earnings, the present value of the payoff to training is $\$ 6,695$, which exceeds the average cost of $\$ 6,568$ in 1990 . This calculation ignores the time costs of participants while they undergo training.
} 
The following calculation indicates approximately how large a sample is required to draw reasonably precise inferences. ${ }^{12}$ Suppose a standard error of about $1 \%$ is desired. If we take Regnér's (1993) sample and estimates as representative, we would need a sample of roughly 41,000 observations to achieve a standard error of .01 , compared to the actual sample of 5,000 observations. We feel that Björklund's $(1990 ; p .12)$ recommendation is worth repeating, "More attention must be paid to these .- less glamorous -- issues of data quality in order to get estimates of reasonable precision." In light of Heckman and Smith's (1993) finding that JTPA experimental and nonexperimental evaluations yield similar results when the comparison sample for nonexperimental sample is carefully selected, we feel this suggestion is particularly prescient.

There is an even smaller set of studies to review that examine the effect of training on subsequent employment probabilities. A careful study by Björklund (1989) finds that retraining programs raise the probability participants are subsequently employed by 4.4-5.5 percent if a linear control function is estimated and by $2-8$ percent if a fixed effects model is estimated, depending on the period. Only the $8 \%$ estimate is significantly different from 0, however. Duration models estimated by Korpi (1992) indicate that longer experience in labor market programs is associated with greater employment stability for youths in Stockholm, and that youths who found jobs directly after participating in manpower programs tended to stay on the jobs longer.

Until sufficient data are available to make precise estimates for Sweden, we believe

\footnotetext{
${ }^{12}$ Another issue to consider is the proper statistical methods and specification to estimate the payoff to job training.
} 
that estimates for the U.S. could prove informative for Sweden. The U.S. literature consistently finds that job training programs have their largest payoff for women. Men tend to have smaller payoffs, and the available estimates for youths suggest that training has no effect, or possibly negative effects, on their subsequent labor market outcomes (see LaLonde, 1992). Although the selection into training programs and the content of programs in Sweden are likely to be quite different, the American estimates may provide a rough indication of the likely returns in Sweden. In the absence of compelling evidence to the contrary, we suspect that a similar qualitative pattem will hold in Sweden. Moreover, the small payoff to training based on the weighted-average study in Figure 3 is consistent with the modest payoffs found in the American literature. All of this suggests to us that one should not expect heroic returns from job training programs. The benefits may justify the costs (especially in Sweden because of pre-existing distortions noted earlier), but the returns are likely to be in the neighborhood of $3 \%$ higher income per year.

\section{Beveridge Curve}

The stability of the unemployment-vacancy relationship, or Beveridge curve, is one of the features of the Swedish labor market that many observers have pointed to. One possible explanation for the stable Beveridge curve in Sweden is that active labor market policies have improved the matching of workers to vacancies. But there are alternative explanations as well. First, the public relief jobs and training programs may mask unemployed workers. Second, public sector employment has grown rapidly in Sweden, with the percent of Swedish workers directly employed by the government increased from 
$20 \%$ in 1965 to $38.2 \%$ in 1985 . The increase in public sector employment is even more dramatic for women, rising from $29.5 \%$ in 1965 to $54.8 \%$ in 1985 . Government employment may have soaked up workers who otherwise would be unemployed, preventing an outward shift in the Beveridge curve. ${ }^{13}$ We explore these alternative explanations for the stable Beveridge curve.

We consider two sources of unemployment data: labor force survey data and register data. Panel A of Figure 4 documents the stability of the Beveridge curve using biannual unemployment data from the labor force survey. Panel B of Figure 4 contains the corresponding plot using register data. The unemployed counted in the register data consist of people looking for work and immediately available to take a job. In both figures the vacancy rate is measured by the number of vacancies listed in the register divided by the labor force.

The unemployment-vacancy rate relationship is fairly stable over time when the unemployment rate is derived from the labor force survey. The register data, by contrast. indicate that the unemployment-vacancy relationship shifted in somewhat between 1990 and 1992 (see Panel B). Both of these patterns present a sharp contrast with most other industrialized countries, which experienced a shift out of the unemployment-vacancy locus in the 1970s and 1980s. We utilize the register data in our county-level analysis because the relatively small sample size in the labor force șurvey would induce considerable sampling variability in county-level estimates. Our goal then is to explain why the Beveridge curve has shifted in for Sweden.

\footnotetext{
${ }^{13}$ This explanation is hypothesized by Lindbeck (1990) and OECD (1992), for example.
} 
Table 5 presents estimates of the Beveridge curve using county-level data for Sweden for 1981-91. In the first four columns the unemployment rate derived from the registers is the dependent variable. Columns 5 and 6 contain estimates that use a broader measure of the unemployment rate as the dependent variable; the broader measure also counts workers on public relief jobs, training programs, and youth programs as among the unemployed. Results with either dependent variable cast some doubt on the importance of public sector employment for the stability of the Beveridge curve in Sweden.

The regression reported in column (1) reveals a negatively sloped relationship between the unemployment rate and the vacancy rate. Notice that the coefficient on the linear time trend reported in column (2) indicates that the county-level Beveridge curve has shifted in, as expected from Panel B of Figure 4. In the model in column (3) we substinte a variable measuring the proportion of workers in the county who are employed in the public sector for the time trend. The estimates in column (3) are consistent with the view that public sector employment has absorbed unemployed workers, as the public sector share has a negative and statistically effect on the county unemployment rate. However, once we add a linear year trend to the model in Column (4), the public sector employment variable changes sign. Moreover, the year trend is hardly affected by the inclusion of the public sector employment variable. In columns (4) and (5) we use the broader definition of the unemployment rate. These results also indicate that the Beveridge curve has shifted in, and . that the proportion of workers employed in the public sector has a positive effect on unemployment when a linear time trend is included.

From the estimates in Table 5, one may be tempted to conclude that a growing 
public sector absorbed many unemployed workers, only that the growth in public sector employment was roughly constant making it difficult to distinguish from a linear time trend. In other words, including both public sector employment and the time trend causes a multicollinearity problem. Although this interpretation is possibly correct, the time path of public sector employment differed across counties, enabling us to estimate the model with both variables in columns (4) and (6). Importantly, the standard error of the estimate for the proportion in the public sector increases only slightly once the time trend is added to the model, suggesting that multicollinearity is not a serious problem.

We are also aware that a valid criticism of the regressions in Table 5 is that public sector employment is possibly an endogenous variable. Nevertheless, we consider these results suggestive that growing public sector employment does not account for the inward shift of the Swedish Beveridge curve. In addition, when we use a broader measure of unemployment - one that includes program participation as well as open unemployment -we still find that the Beveridge curve has shifted in. Thus, we have no satisfactory explariation for the time-trend in the Beveridge curve in Sweden.

Although the reasons for Sweden's unemployment-vacancy relationship are unclear, we should stress that a stable or inward shift of the Beveridge curve is not necessarily a virtue if the unemployment rate has increased. If the Beveridge curve had shifted out, at least there would be substantial job vacancies at the prevailing high unemployment rate, and the issue would be matching people to jobs. But in Sweden's current economic environment the level of vacancies is low and the level of unemployment is high. Unless we were confident of steps that would move the Swedish labor market down along a stable 
Beveridge curve, this is not a desirable situation.

\section{International Evidence on Active Labor Market Programs}

Our main approach in this paper has been to try to measure the impact that specific labor market programs (such as public relief work) have on key outcome variables (such as construction worker employment). For the programs and outcome measures that we have been able to study, this analysis provides little support for the view that Sweden's labor market policies have greatly enhanced the operation of the labor market. Most of the favorable impression of active labor market policies, however, is due to a different approach -- cross-country analyses. In these studies, an aggregate measure of a country's labor market performance (usually the unemployment rate) is related to institutional characteristics of the country, such as variables measuring the extent of its active labor market programs, and other economic variables (e.g. Bean, Layard and Nickell, 1986, and Layard, Nickell and Jackman, 1991). The international evidence has generally found that countries with greater spending on active labor market policies tend to have lower unemployment. In this section we review, update, and evaluate the international evidence on the effectiveness of labor market programs.

In their influential book, Layard, Nickell and Jackman (1991, Ch. 1) present a crosscountry regression of the average unemployment rate for 1983-88 on a variable measuring active labor market programs and several other variables. Their sample consists of 20 OECD countries. Active labor market programs are measured by expenditures on these programs per unemployed person relative to GDP per capita in 1987. Their regression 
coefficients (t-ratios in parentheses) are reported below:

Unemployment rate $(\%)=0.24(0.1)$

$+0.92(2.9)$ benefit duration (years)

+0.17 (7.1) replacement ratio (\%)

- 0.13 (2.3) active labor market spending (\%)

+2.45 (2.4) coverage of collective bargaining ( $(1-3)$

$-1.42(2.0)$ union co-ordination (1-3)

- 4.28 (2.9) employer co-ordination (1-3)

$-0.35(2.8)$ change in inflation (\% points)

$$
R^{2} \text {-adj. }=0.91 ; \quad \text { s.e. }=1.41 ; \quad \mathrm{N}=20 \text {. }
$$

The statistically significant point estimate on the active labor market variable implies that the derivative of the unemployment rate with respect to the share of the labor force in programs equals -1.5 , so that the reduction in open unemployment exceeds the direct effect of lifting people out of unemployment by means of active labor market policies (see Calmfors, 1994, footnote 18).

In related work, Zetterberg (1993) pools time-series data for 19 OECD countries for the period 1985-1991, and regresses unemployment on the ratio of expenditures on active labor market measures relative to total expenditures on labor market policies. Consistent with Layard, et al., he finds that as the share of expenditures on labor market policies increases, the national unemployment rate declines. 
We think there are two major weaknesses with the cross-country analyses which limit their usefulness in evaluating active labor market programs. The first problem arises because the source of variability in the countries' labor market policies is unclear. In this situation, one would like to control for a great many variables that might influence the unemployment rate and national labor market policy. However, with only 20 observations. the number of variables that one can hold constant is greatly restricted.

A related issue is that cause and effect in the cross-country regressions are very difficult to ascertain. If a nation is in a prolonged downturn, it may be difficult to deny generous unemployment insurance benefits to unemployed workers. In this scenario, high unemployment causes high UI replacement rates and long benefit durations, not vice versa. A possible approach to solving this simultaneity bias problem would be to instrument for the labor market variables, but valid instrumental variables are difficult to find for this problem.

A similar concern arises with the active labor market variables. As pointed Grubb (1993) and OECD (1993) point out, spending on active labor market measures tends to rise less than in proportion with unemployment in most OECD countries. As spending on unemployment benefits typically varies approximately in proportion to unemployment, this has induced a negative correlation between unemployment and spending on active labor market measures per unemployed worker, and between unemployment and the share of total labor market program expenses devoted to active labor market programs. "

\footnotetext{
${ }^{14}$ This point is demonstrated in OECD (1993, Annex 2.A), which shows that the significant effect of active labor market programs found by Layard, et al. vanishes when spending on active labor market programs is instead related to the total wage bill.
} 
Our second, and perhaps more important concem, is that the cross-country evidence on the active labor market programs is not very stable over time. The cross-country evidence has been conducted mainly using data for the 1980 s, when the unemployment rate in Sweden and other countries with extensive active labor market programs was relatively low. The situation has changed quite dramatically in the early 1990s. To probe the stability of the international evidence, we have conducted a cross-country analysis of the 1993 unemployment rate that is similar in spirit to the work of Layard, Nickell, and Jackman (1991) and Zetterberg (1993)

Specifically, we regress the unemployment rate in 1993 on two measures of active labor market programs, the change in inflation, and the same institutional variables used by Layard, Nickell, and Jackman (1991). For comparison, we present corresponding estimates for the years $1983-88$, the period analyzed by Layard, Nickell, and Jackman. We measure the importance of active labor market programs in two ways. First, we calculate the fraction of GDP spent on active labor market programs. Second, we use Zetterberg's (1993) variable, which equals the share of expenditures on active labor market measures relative to total expenditure on labor market programs. Both of these measures have problems. Most obviously, active labor market expenditures relative to GDP may rise when unemployment rises because more people become eligible for programs - the simultaneity problem we noted previously. The simultaneity bias is likely to impart the opposite bias for. the share of expenditures on active labor market programs relative to total expenditures on labor market programs. But bear in mind that our main interest here is in examining whether the effect of the active labor market variables has changed between the 1980's and 
1993, not whether the estimates are biased at any one time. 15 $^{2}$

Table 6 summarizes the main regression results. ${ }^{16}$ The table indicates a striking change in the coefficients for the active labor market variables. In the 1983-88 period both active labor market variables have a negative association with unemployment, whereas they both have a positive association in 1993. The t-ratio for a test of the difference between the estimates for the active labor variable in Columns (3) and (4) is 1.89 . It is also worth noting that the union coverage and union coordination variables have changed signs and become statistically insignificant in 1993. On the other hand, the duration and generosity of unemployment insurance benefits continue to have a positive association with the unemployment rate, and an increase in the inflation rate continues to have a negative (albeit statistically insignificant) effect on the national unemployment rate in 1993.

One could argue that 1993 is an aberration - that the international evidence in other years suggests that active labor market programs have reduced unemployment. But together with the statistical issues that we raised previously, we think the results of the updated cross-country regressions challenge the favorable impression of active labor market programs that several observers have drawn from international comparisons.

\footnotetext{
${ }^{13}$ The correlation between Layard, Nickell and Jackman's active labor market variable (expenditures on active labor market programs per unemployed worker relative to GDP per capita in 1982) and ours (the fraction of GDP devoted to active labor market programs circa 1993) is .82 .

${ }^{16}$ Because the sample size is small, in each model we use the largest available sample. This leads to different samples of countries in different years. However, our results are qualitatively similar when we restrict the samples to a common set of countries.
} 


\section{Comparison of Regional Evolutions}

Finally, we examine the responsiveness of employment and unempioyment to regional shocks in Sweden. This analysis is motivated by two issues. First, if Sweden's labor market policies are unusually successful, we would expect economic shocks to have less persistent effects in Sweden than in other countries. Second, Sweden's past record of adjustment to economic shocks may tell us something about how the labor market will react to the current economic downturn.

Specifically, we investigate the evolution of employment and unemployment using pooled time-series and cross-sectional data for the 24 counties in Sweden. As a first look, Figure 5 presents a plot of the unemployment rate in 1992 against the unemployment rate in 1976 using data on each of the 24 counties in Sweden. There is considerable persistence in the level of unemployment across regions in Sweden. This is similar to the pattern found for regions in the France, Germany, Spain, and the U.K. by Decressin and Fatas (1993), but quite different from the pattern for states in the U.S. found by Blanchard and Katz. Figure 6 shows a plot of each county's percentage growth in employment 1983-91 against its growth between 1976-83. There appears to be little persistence in employment growth rates across counties in Sweden. Again, the pattern for Sweden more closely resembles the European pattern found by Decressin and Fatas than the U.S. pattern found by Blanchard and Katz

Following Blanchard and Katz (1992), we define $\Delta \eta_{i t}$ as the change between year $t$ and $t-1$ in the logarithm of employment in county $i$ minus the change in the logarithm of employment in Sweden nationwide between year $t$ and $t-1$. We estimate the same 
univariate process for employment as Blanchard and Katz:

(2) $\Delta \eta_{i t}=\alpha_{i}+\beta(L) \Delta \eta_{i-1}+\varepsilon_{i t}$

where we allow four lags in $\Delta \eta_{i+1}, \alpha_{i}$ represents a county fixed effect, and $\varepsilon_{i t}$ is an idiosyncratic error term. ${ }^{17}$

Results are presented in Table 7, and the implied impulse response function is shown graphically in Figure 7. For comparison, we also report Blanchard and Katz's estimates for the 50 U.S. states. Regional shocks to relative employment have lasting effects in Sweden; they are $86 \%$ of their original size after 20 years. In the U.S. regional employment shocks also have permanent effects, but they tend to be amplified over time. Interestingly, Decressin and Fatas (1993) find that the Swedish pattern is more typical of other European countries." The U.S. would thus seem to be the outlier here, not Sweden.

Next we examine the evolution of relative unemployment rates. Specifically, we follow Blanchard and Katz and estimate:

(3) $\mu_{k}=\alpha_{1}+\beta_{1} \mu_{n-1}+\beta_{2} \mu_{i n-2}+\varepsilon_{i t}$

17A Dickey-Fuller test did not reveal a unit root in the Swedish county-level employmentseries. Nevertheless, we estimate the same specifications as Blanchard and Katz for comparability.

10Decressin and Fatas's results are not directly comparable to our estimates and to Blanchard and Katz's because they deviate regional employment from country-specific coefficients times aggregate European employment. But their country coefficients are close to one, and they report similar results for the U.S. as Blanchard and Katz when they apply their procedure to U.S. data. 
where $\mu_{i t}$ is the unemployment rate in county $i$ in year $t$ minus the aggregate unemployment rate in Sweden in year $t, \alpha_{i}$ is a county effect, and $\mu_{i n-1}$ and $\mu_{i \cdot 2}$ are one and two year lags of the relative unemployment rate.

As shown in Table 7 (Columns (3) and (4)) and Figure 8. the relative unemployment rate series in both Sweden and the U.S. displays less persistence than the relaive employment growth series. Half of the impact of an innovation in a county's relative unemployment rate is predicted to dissipate three years after the initial shock. Ten years after a shock, the innovation is predicted to have completely dissipated.

The implied impulse response functions for the unemployment rate are quite similar in Sweden and the U.S., and Decressin and Fatas find a similar pattern for regional data in several European countries. Our finding of similar regional evolutions in the relative . unemployment rate series in Sweden, the U.S., and Europe suggests that active labor market programs in Sweden have not had a marked effect on unemployment adjustment in regional labor markets in Sweden.

\section{VIl. Conclusions}

We conclude by considering what our review of the literature and original analysis imply for the current problems facing the Swedish labor market. We also consider possibie lessons from Sweden's experiences for labor market policy in the U.S. and elsewhere.

One important question that we can partially address is whether the recent dramatic increase in unemployment in Sweden is likely to have a persistent effect. We can base our estimate on the estimated unemployment rate equation in Table 7 if we make two strong 
assumptions: (1) the regional shocks that identify the autoregressive models in Table 7 have similar effects as the shocks causing the current depression in the Swedish labor market; and (2) the 7 percentage point increase in the unemployment rate in Sweden between 1990 and 1993 is the entire innovation to the unemployment rate series. If these assumptions are valid, the coefficients in Table 7 imply that the Swedish unemployment rate will gradually decline, but will still be at historically high levels for at least the next few years, and probably longer.

Our analysis also suggests that the active labor market programs are not as effective at combatting unemployment or enhancing workers' skills as some observers believe. How might certain policy changes affect the labor market programs, especially in the current high unemployment environment? The answer to this question is particularly important if the high rate of unemployment persists in the future. Indeed, relatively generous unemployment benefits (compared to the U.S.) is a reason why one might expect the high rate of unemployment to persist.

First, Sweden's UI fund benefits are very generous by U.S. standards and are available for a long duration. Benefits last for 300 days, which is more than twice the maximum duration of unemployment benefits in the U.S. Furthermore, the maximum duration of unemployment benefits in Sweden may be effectively longer given the possibility of re-qualifying for benefits after working on public relief jobs or undergoing retraining. The extent to which individuals rotate between receiving unemployment benefits and participating in labor market programs should be investigated. If this appears to be a widespread phenomenon, one possible response would be to limit the total duration that 
individuals may receive unemployment benefits in a specified window of time.

A second possible response is an expanded set of programs to encourage entrepreneurial activity by unemployed workers. Experimental evidence and experience in the U.S. suggests that a minority of unemployed workers are interested in self-employment. and that government assistance can help to increase the number of unemployed who start their own businesses. For example, the state of Washington has had favorable results from providing unemployment benefits in a lump sum to those who are interested in obtaining seed capital to start their own business (U.S. Department of Labor, 1992). In addition, training in business activities and other support services may prove useful. The social reward to pursuing this kind of a policy is likely to be greater in Sweden where high marginal tax rates discourage entrepreneurial ventures. Another possible issue to study is that to encourage more entrepreneurial activities the government might allow some "tax and regulation havens" in which start-up businesses are exempted from tax and regulatory requirements for a specified period of time. Although only a small minority of the unemployed could possibly become successful entrepreneurs, this is a margin in which employment could possibly be expanded, especially in a downtum.

Third, our review of studies of training lead us to the same conclusion reached by Robert Flanagan six years ago: "There is disappointingly little evidence that these expenditures have improved the productivity of the Swedish work force." Although the handful of studies on the impact of training employ state-of-the-art statistical methods, the data have proved insufficient for deriving precise estimates of the payoff to training. Aggregating over several studies, we conclude that the payoff is modest, at best. The U.S. 
evidence supports a similar conclusion. Furthermore, the immediate benefit of job training when the labor market is weak is likely to be smaller than when the labor market is strong. An important question is whether some training expenditures could be more profitably redirected, perhaps toward programs that would stimulate aggregate demand. From a research standpoint, it would be useful if any policy changes could be implemented in such a way as to facilitate evaluation of the impact of the policies. Specifically, this may include selection of individuals for certain policies based on an arbitrary criterion (e.g., birthday falls after certain date) and administrative monitoring of nonparticipants and program exhaustees for data collection purposes and subsequent analysis. Finally, our results and those of Gramlich and Ysander (1981) suggest that in the past public relief workers have displaced other workers, on net creating few new jobs in the construction sector. It is possible that displacement effects could be limited by requiring local governments to propose new projects in order to qualify for relief workers. If public relief work assumes a greater role in the current downturn, this issue would be worthy of further study.

What does our analysis imply for the U.S.? The U.S. seems to be moving in the opposite direction of Sweden, having recently elected a President with a platform of "putting people first" by improving the skills of the work force. In addition, unemployment benefits have recently been extended in the U.S. in some regions, whereas the level of benefits was recently cut in Sweden. It is possible that both countries are moving in the "optimal" direction, since the active labor market programs in the U.S. are much smaller than those in Sweden. The optimal level of labor market programs may lie somewhere in 
between the two countries. Nevertheless, Sweden's experience that active labor market programs alone are not capable of fending off high levels of unemployment should be instructive to the U.S. and other countries. Countries should not expect supernormal returns from government labor market programs. Policy makers in eastern European countries who look to Sweden as a model for labor market institutions would be well advised to keep this lesson in mind. 


\section{References}

Susanne Ackum, "Youth Unemployment, Labor Market Programs and Subsequent Earnings", Scandinavian Journal of Economics 93, (1991): 351-543.

Charles Adams, et al., "A Pooled Time-Series Analysis of the Job Creation Impact of Public Service Employment Grants to Large Cities," Joumal of Human Resources 18 (Spring 1983): 283-94.

R Axelsson and K.G. Löfgren, "Arbetsmarknadsutbildningens Privat-och Samhällsekonomiska Effekter", 1992, Rapport 25 fran EFA.

Bean, Charles, Richard Layard and Steven Nickell, "The Rise in Unemployment: A MuliCountry Study", Econometrica vol. 53, no. 2, 1986.

Anders Björklund, "Evaluation of Training Programs - Experiences and Suggestions for Future Research", Discussion paper 89-13, 1989, Wissenchaftszentrum Berlin.

Anders Björklund, "Evaluation of Training Programs," Finnish Economic Papers 3 (Spring 1990): 3-13.

Olivier Blanchard and Lawrence Katz, "Regional Evolutions," Brookings Papers on Economic Activity 1 (1992): pp. 1-75.

Michael Borus and Daniel Hamermesh, "Estimating Fiscal Substitution by Public Service Employment Programs," Journal of Human Resources 13 (Fall 1978): 561-65.

Lars Calnfors and Anders Forslund, "Real-Wage Determination and Labor Market Policies: The Swedish Experience," The Economic Journal 101 (September 1991): 1130-48.

Lars Calmfors, "Lessons from the Macroeconomic Experience of Sweden," IIES Seminar Paper No. 522, 1992.

Lars Calmfors and Harald Lang, "Macroeconomic Effects of Active Labor Market Programs -- Basic Theory," IIES Seminar Paper No. 541, 1993.

Carling, Kenneth, Pex-Anders Edin, Anders Harkman, and Bertil Holmlund, "Unemployment Duration, Unemployment Benefits, and Laborm Market Programs in Sweden," Working Paper 1994:12, Department of Economics, Uppsala University.

Grubb, David, "Some indirect Effects of Active Labor Market Policies in OECD Countries", mimeo., OECD, Paris, 1993. 
Jörg Decressin and Antonio Fatas, "Regional Labor Market Dynamics in Europe and Implications for EMU," mimeo., IMF, Washington, D.C., 1993.

Per-Anders Edin, "Individual Consequences of Plant Closures", Studia Oeconomica Upsaliensia 15, 1989.

Per-Anders Edin, Bertil Holmlund and Thomas Ostros, "Wage Behavior and Labor Market Programs in Sweden: Evidence from Micro Data," Uppsala University, Working Paper No. 1993:1, December 1992.

Per-Anders Edin and Robert Topel, "Wage Policy and Restructuring: The Swedish Labor market Since 1960," this volume.

Robert Flanagan, "Efficiency and Equality in the Swedish Labor Markets," The Swedish Economy B. Bosworth and A. Rivlin (eds.), (Washington, D.C.: The Brookings Instintion, 1987): $125-186$.

Edward Gramlich and Bengt-Christer Ysander, "Relief Work and Grant Displacement in Sweden," in Eliasson, Holmlund and Stafford, Studies in Labor Market Behavior, 1981, pp. 139-66.

James Heckman and Jeffrey Smith, Presentation on JTPA Evaluation Project, NBER. October 1993.

George Johnson and James Tomola, "The Fiscal Substitution Effects of Alternative Approaches to Public Service Employment," Journal of Human Resources 12 (Winter 1977): 3-26.

Korpi, Tomas, "Employment Stability Following Unemployment and Manpower Programs." Stockholm Research Reports in Demography, Stockholm University, 72, December 1992.

Robert LaLonde, "The Earnings Impact of U.S. Employment and Training Programs," University of Chicago, mimeo., December 1992.

Richard Layard, Stephen Nickell, and Richard Jackman, Unemployment: Macroeconomic Performance and the Labor Market (Oxford: Oxford University Press, 1991).

Assar Lindbeck, "The Swedish Experience," IIES Seminar Paper No. 482, 1990.

Organization for Economic Co-operation and Development, OECD Economic Survevs: Sweden 1991/1992 (Paris: OECD, 1992).

Organization for Economic Co-operation and Development, (1993), Unemplovment Outlook Paris. 
Regnèr, H. "Choosing Among Alternative Non Experimental Methods for Estimating the Impact of Training: New Swedish Evidence," mimeo, Swedish Institute for Social Research. Stockholm University, Meddelende 8:1993.

Frank Stafford, "Unemployment and Labor Market Policy in Sweden and the United States," in Eliasson, B. Holmlund and F. Stafford, Studies in Labor Market Behavior (1981): pp. 139-66.

U.S. Department of Labor, Employment and Training Administration, "The Washington Reemployment Bonus Experiment: Final Report," Washington, D.C., UI Occasional Paper $92-6,1992$.

Zetterberg, Johnny, (1993), "Arbetsloshet, Arbetsmarknadspolitik och Loneforhandlingssysytem". In Politik mot Arbetsloshet. Betankande av EFA, SOU 1993:43, Stockholm. 
Figure 1

Swedish Unemployment Rate, cy Ha!: yaar 1970-1993

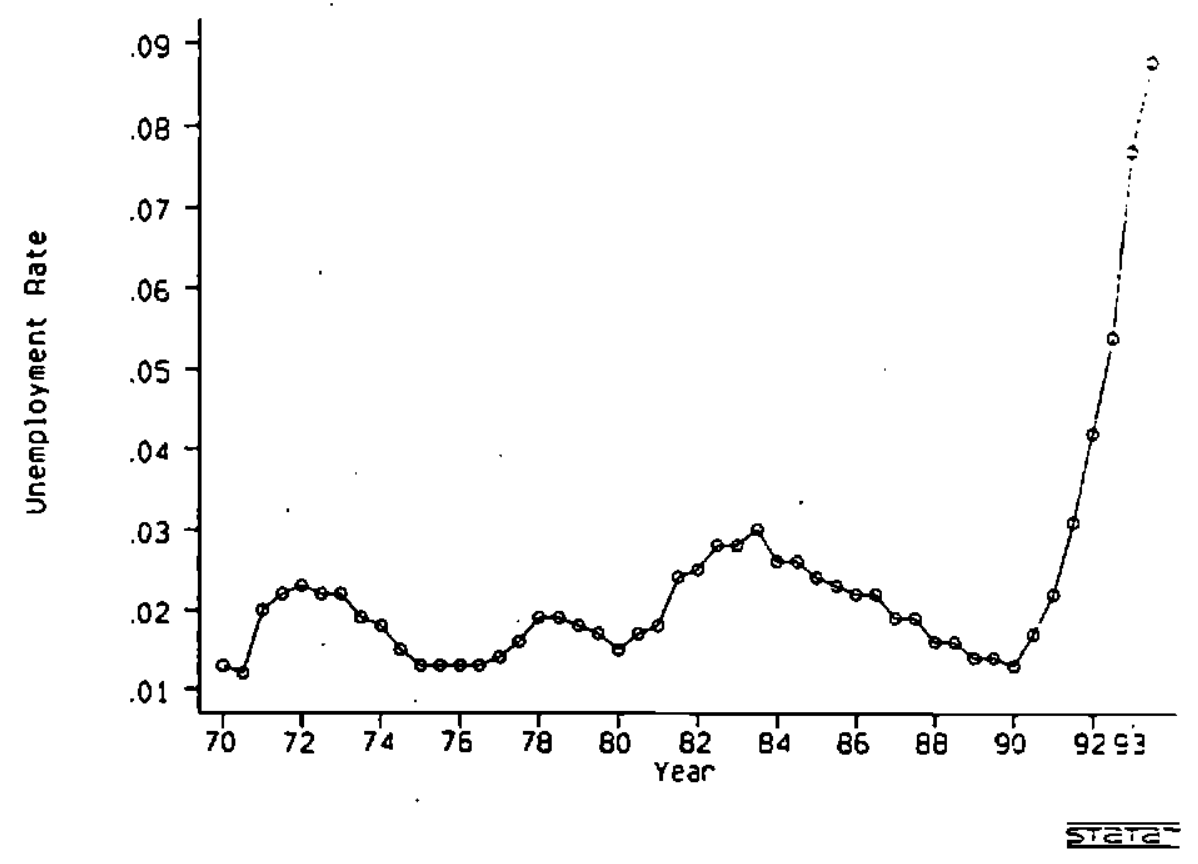




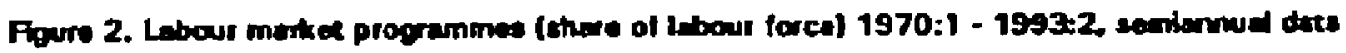

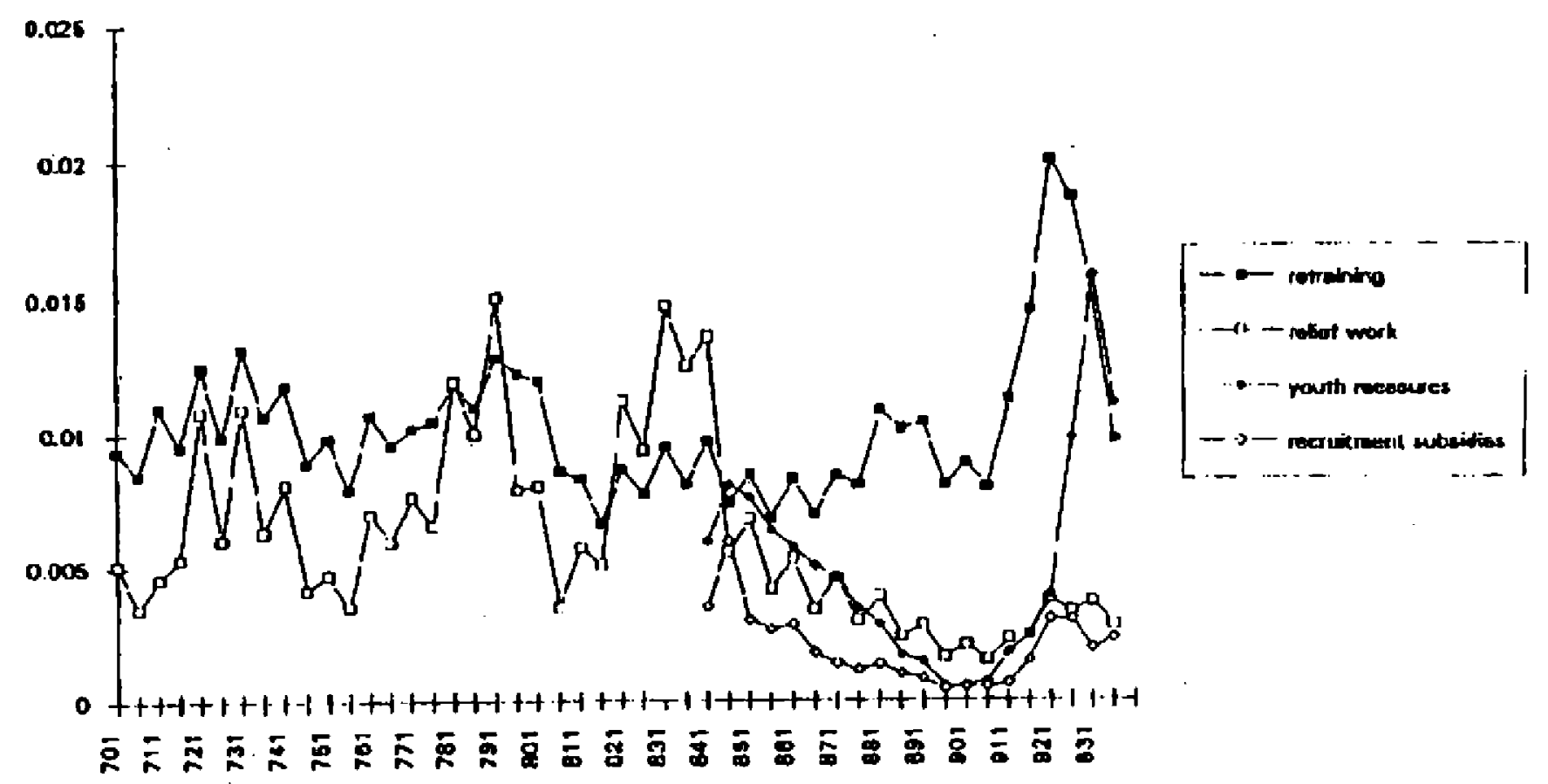




\section{Flgure 3}

Returns to Retraining Programs in Sweden - Selected Estimates
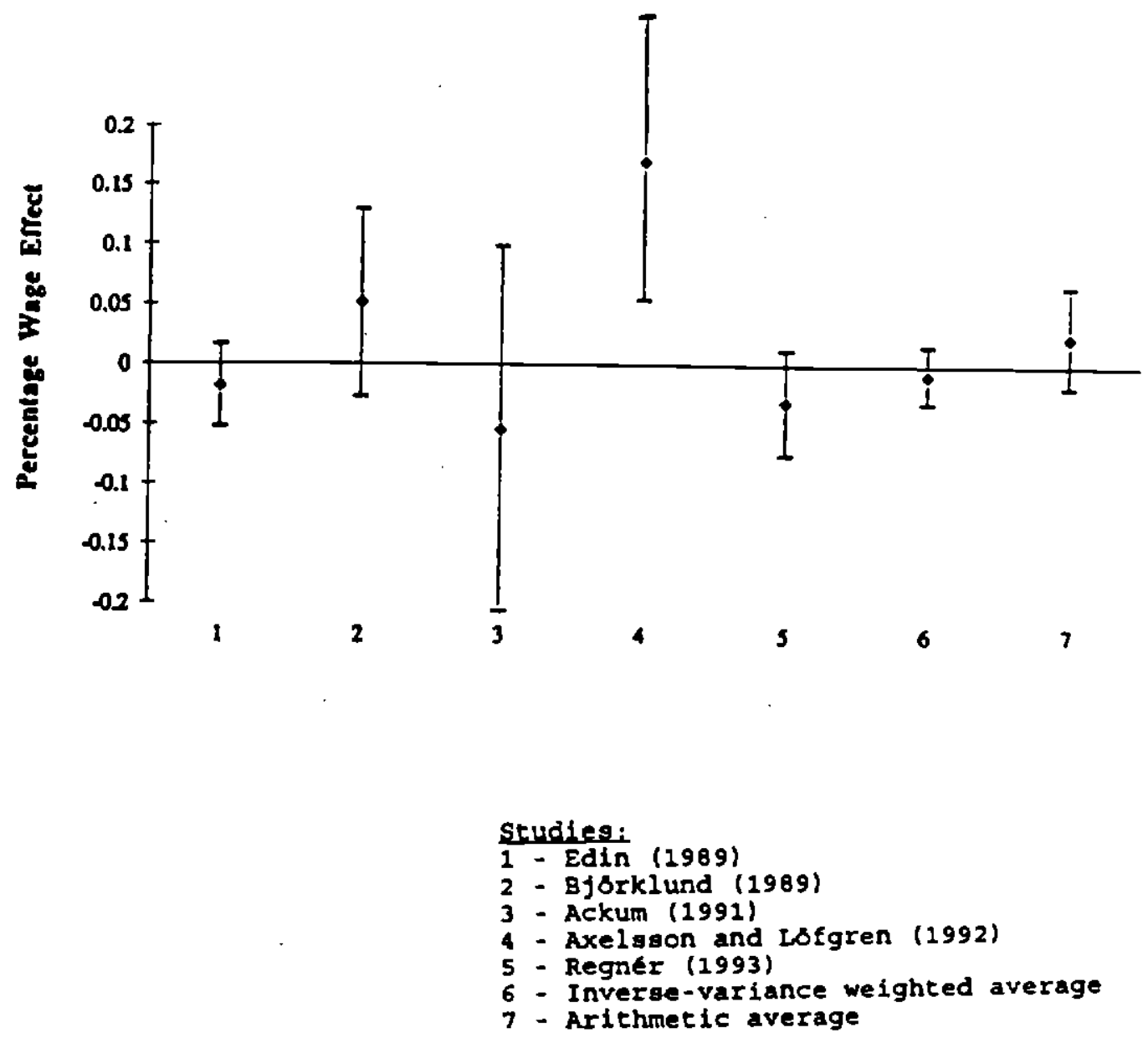
F1gure 4
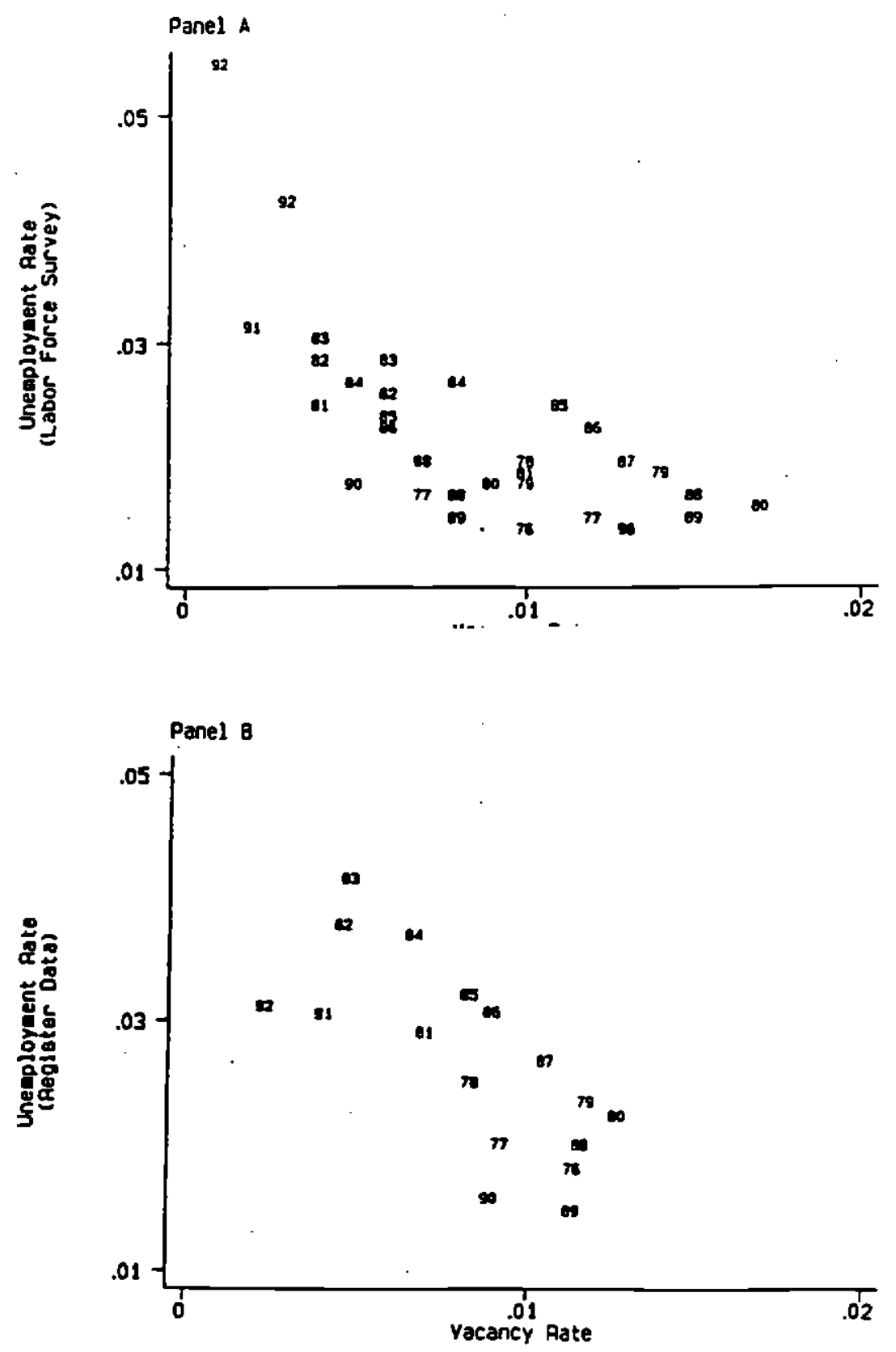


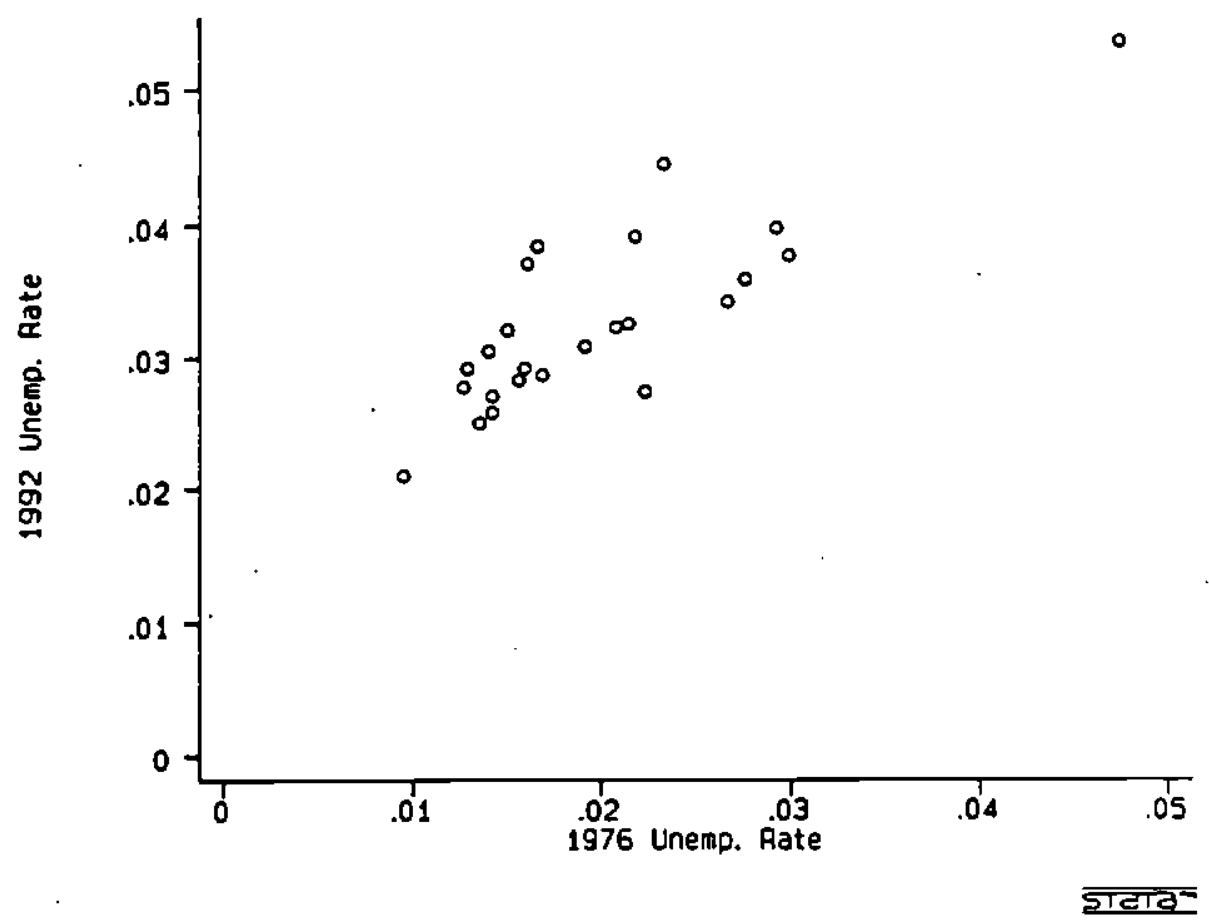

Flgure 5 


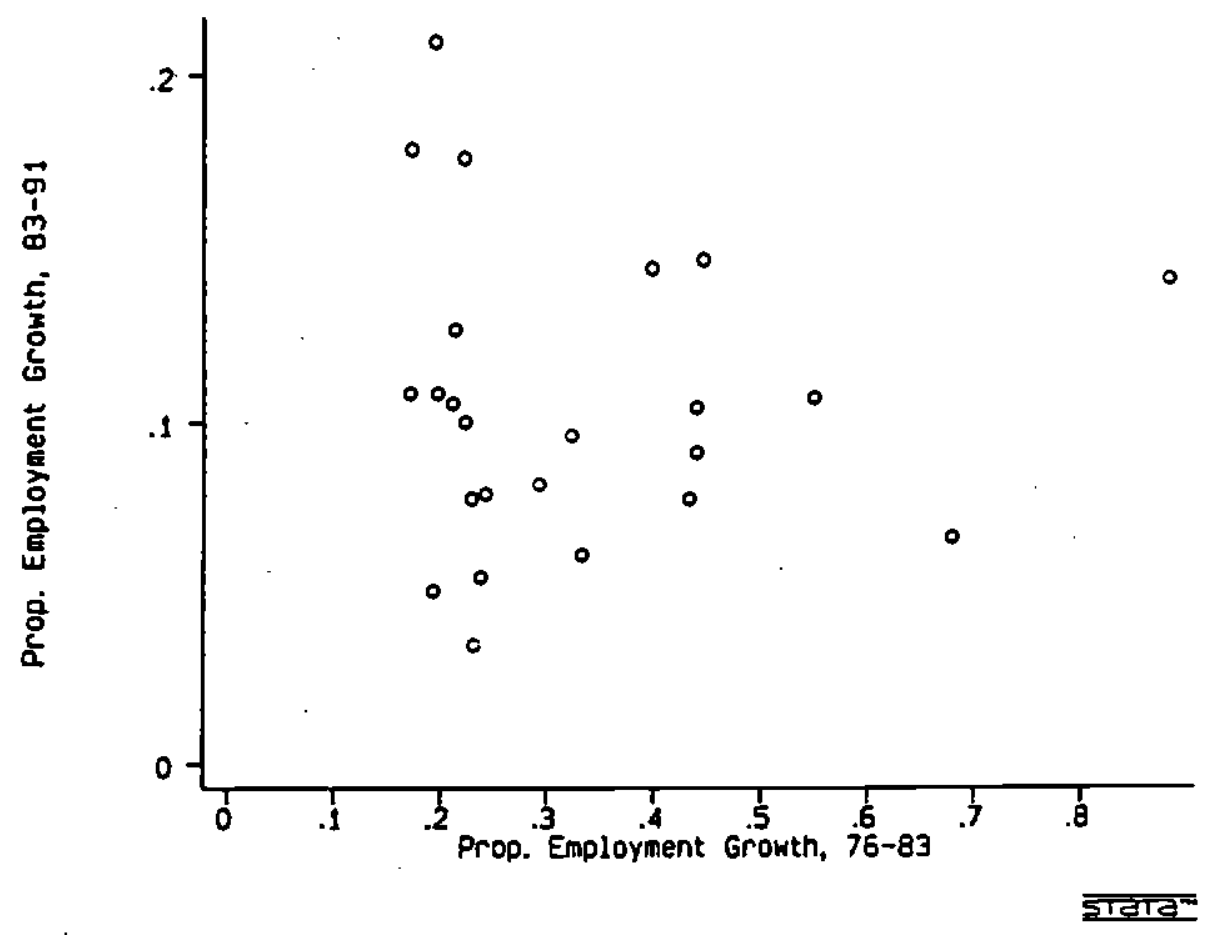

F1gure 6 
Figuro 7

Impulse Response Fn. -- Sweden \& U.S.

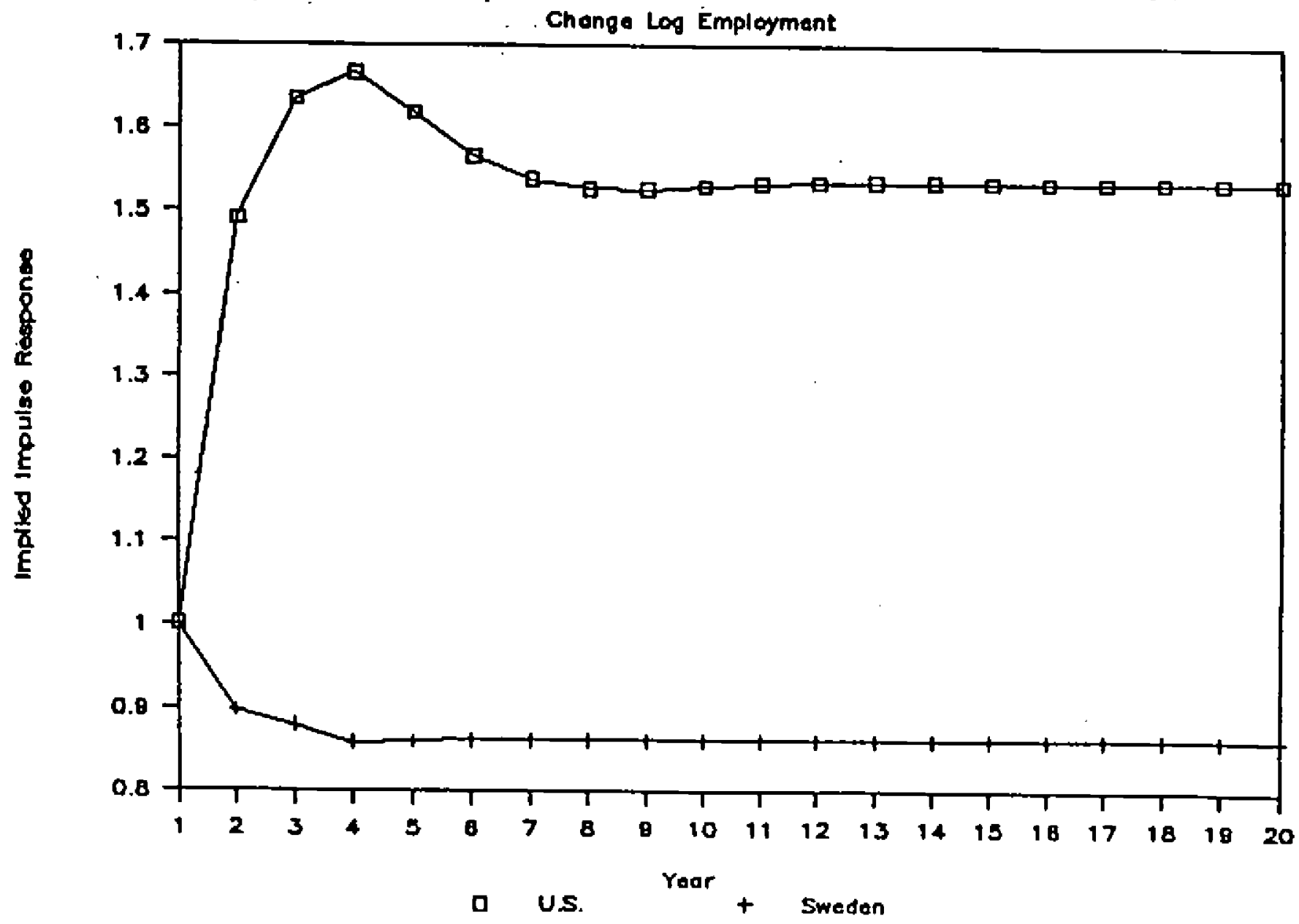


Figure 8

Impulse Response Fn. -- Sweden \& U.S.

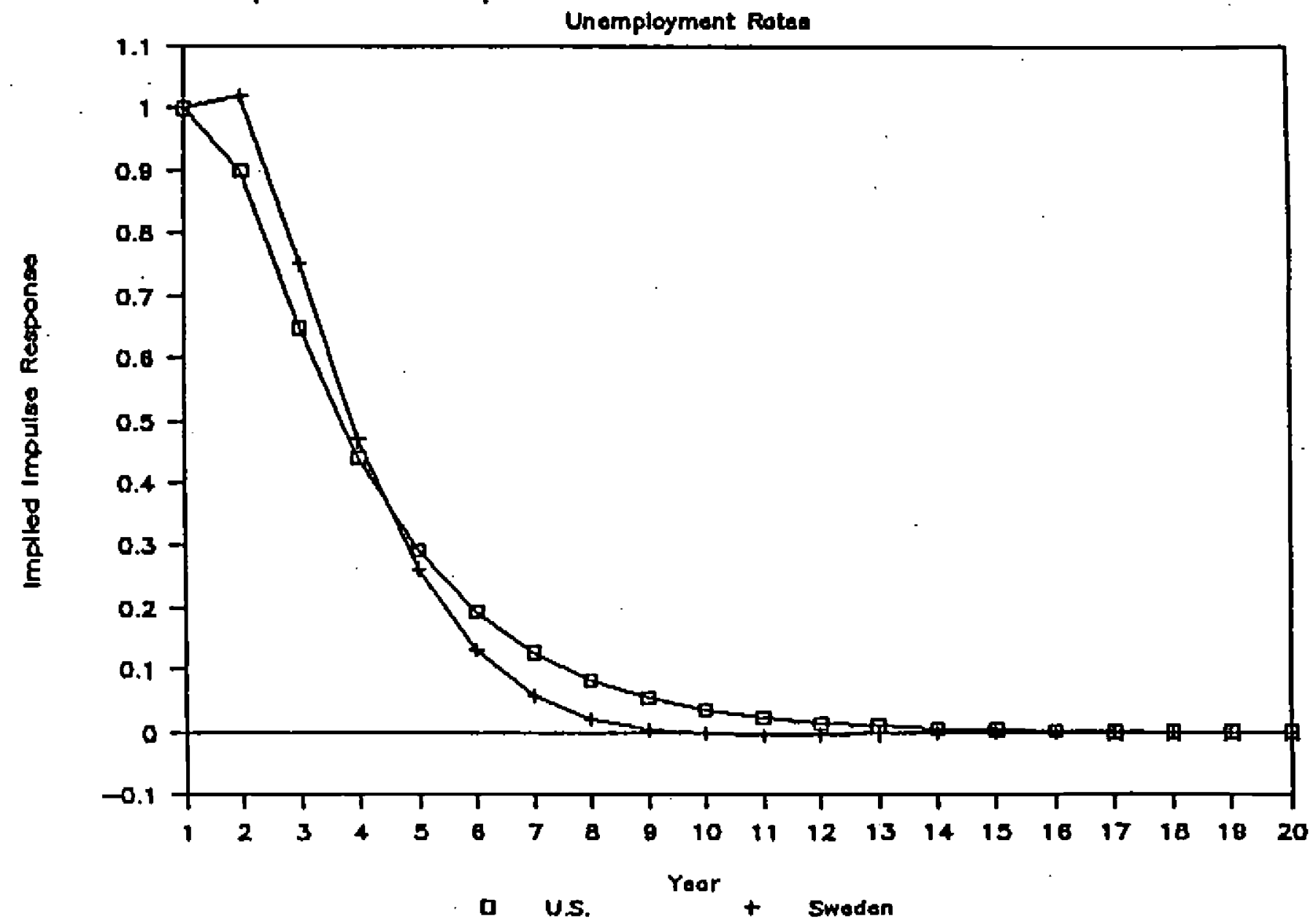


Table I

Comparison of Labor Market Policies in Sweden, the U.S., and Gernany

\begin{tabular}{|c|c|c|c|c|}
\hline Labor Market Policy & $\begin{array}{l}\text { Sweden } \\
\underline{1982}\end{array}$ & $\begin{array}{l}\text { Sweden } \\
\underline{1990}\end{array}$ & $\begin{array}{l}\text { U.S. } \\
2990\end{array}$ & $\begin{array}{c}\text { Germany } \\
2990\end{array}$ \\
\hline $\begin{array}{l}\text { Average unemployment } \\
\text { compensation per recipient }\end{array}$ & 510.843 & $\$ 17,655$ & 52.221 & $\$ 12.792$ \\
\hline $\begin{array}{l}\text { Average training costs } \\
\text { per recipient }\end{array}$ & $\$ 9,214$ & $\$ 6,568$ & $\$ 2.035$ & NA. \\
\hline $\begin{array}{l}\text { Trainees as a proportion of } \\
\text { labor force }\end{array}$ & 0.0085 & 0.0094 & 0.0103 & 0.0102 \\
\hline $\begin{array}{l}\text { Trainees as a proportion of } \\
\text { unemployed }\end{array}$ & 0.32 & 0.62 & 0.19 & 0.16 \\
\hline $\begin{array}{l}\text { Public relief workers as } \\
\text { a proportion of unemployed }\end{array}$ & 0.39 & 0.12 & $0 \cong 0$ & 0.04 \\
\hline $\begin{array}{l}\text { Proportion of GNP devoted to } \\
\text { labor market policies }\end{array}$ & 0.039 & 0.028 & 0.004 & 0.021 \\
\hline
\end{tabular}

Notes:

a. All monetary figures are in 1990 U.S. dollars. Swedish kronor

were converted to dollars using the exchange rate, and were

converted from 1982 to 1990 dollars with the CPI-U.

b. Only certified UI fund benefits are included for Sweden.

c. Net training coot are reported for Sweden (i.e., average unemployment benefitg have been subtracted off). For U.S., training programs include JTPA and Job Corps.

d. Only trainees who recelve government compensation are included for Germany. 
Table 1 - Continued

e. Policies included in U.S. Eigure are: job training, summer youth employment, unemployment benefits, and employment services. Policies included in Sweden figure include: job training, relief, worker, youth measures, unemployment benefits, and handicapped programs. Policies included for Germany include: unemployment benefits, retraining, employment services, pre-retirement benefits, subsidized employment programs, compensation for short-time workers, compensation of construction workers during inclement weather, and administrative costs.

Sourcea: Unemployment benefit data for U.S. are from 1991 Green

Book, p. 466. Training data for the U.S. are from 1991 Green

Book, pp. 1454-1456, and pertain to JTPA IIA, and JTPA IIB, and

Job Corpa programs. Swedish data are from Statistisk Arsbok 1992

and OSCD Economic surverg. German data are from Stabistisches Jahrbuch

1993 and zahlen zur Whrgehafelichtlichen Entwicklung der

Bundergrepublik Deutgchland 1992, Ingtitut der Deutschen Wirtschaft. 
Table 2

Displacement Effects of Public Relief Workers

Dependent Variable: Number of Private Construction Workers

\begin{tabular}{|c|c|c|c|c|c|c|}
\hline \multirow{2}{*}{ Variable } & \multicolumn{6}{|c|}{ Model } \\
\hline & (1) & (2) & (3) & (4) & (5) & (6) \\
\hline Relief Workers (t-1) & $\begin{array}{l}-0.65 \\
(0.11)\end{array}$ & $\begin{array}{l}-0.59 \\
(0.17)\end{array}$ & $\begin{array}{l}-0.36 \\
(0.11)\end{array}$ & $\begin{array}{l}-0.59 \\
(0.18)\end{array}$ & $\begin{array}{l}-0.36 \\
(0.13)\end{array}$ & $\begin{array}{l}-0.69 \\
(0.19)\end{array}$ \\
\hline County Dummies & Yes & Yes & Yes & Yes & Yes & Yes \\
\hline Year Dummies & No & Yes & No. & Yes & No & Yes \\
\hline Log Wage $(\times 1,000)$ & - & - & $\begin{array}{c}1.65 \\
(0.22)\end{array}$ & $\begin{array}{r}-12.38 \\
(6.62)\end{array}$ & $\begin{array}{c}1.65 \\
(0.22)\end{array}$ & $\begin{array}{r}-11.88 \\
(6.27)\end{array}$ \\
\hline Vacancy Rate (x 1,000$)$ & - & $\cdots$ & $\begin{array}{c}64.77 \\
(28.31)\end{array}$ & $\begin{array}{c}95.28 \\
(50.36)\end{array}$ & $\begin{array}{c}66.78 \\
(37.89)\end{array}$ & $\begin{array}{r}94.27 \\
(49.83)\end{array}$ \\
\hline Unemployment Rate (x 1,000 ) & - & - & $\cdots$ & -- & $\begin{array}{c}0.97 \\
(12.18)\end{array}$ & $\begin{array}{r}44.64 \\
(23.24)\end{array}$ \\
\hline $\mathbf{R}^{2}$ & 0.98 & 0.98 & 0.98 & 0.98 & 0.98 & 0.98 \\
\hline Sample Size & 384 & 384 & 360 & 360 & 360 & 360 \\
\hline
\end{tabular}

Notes: Standard errors are in parentheses. Equations also include intercept terms. Mean of dependent variable is 9,385. Observations in columns 1-2 are for 1976-91; observations in columns 3-6 are for $1976-90$. There are 24 counties in the sample each year. 
Table 3

Displacement Effects of Public Relief Workers

Dependent Variable: Number of Health and Welfare Workers

\begin{tabular}{lccccccc}
\hline & \multicolumn{7}{c}{ Model } \\
Variable & $(1)$ & $(2)$ & $(3)$ & $(4)$ & $(5)$ & $(6)$ \\
& & & & & \multicolumn{1}{c}{} \\
\hline & & & & & & \\
Relief Workers (t-1) & -2.26 & -1.09 & 0.91 & -0.46 & 0.58 & -0.56 \\
& $(0.39)$ & $(0.59)$ & $(0.40)$ & $(0.62)$ & $(0.43)$ & $(0.63)$ \\
County Dummies & Yes & Yes & Yes & Yes & Yes & Yes \\
Year Dummies & No & Yes & No & Yes & No & Yes \\
Log Wage (x 1,000) & - & - & 12.61 & 48.76 & 17.45 & 53.15 \\
& & & & $(2.02)$ & $(26.55)$ & $(3.09)$ & $(27.09)$ \\
Vacancy Rate (x 1,000) & - & - & 343.95 & 375.34 & 374.06 & 365.43 \\
& & & $(146.90)$ & $(198.88)$ & $(146.39)$ & $(199.17)$ \\
Unemployment Rate (x 1,000) & - & - & - & - & 123.91 & 72.04 \\
& & & & & & $(60.21)$ & $(73.81)$ \\
$R^{2}$ & 0.98 & 0.99 & 0.99 & 0.99 & 0.99 & 0.99 \\
Sample Size & 240 & 240 & 216 & 216 & 216 & 216
\end{tabular}

Notes: Standard errors are in parentheses. Equations also include intercept terms. Mean of dependent variable is 33,140 . Observations in columns 1-2 are for 1982-91; observations in columns 3-6 are for 1982-90. There are 24 counties in the sample each year. 
Table 4

Vector Autoregressions for Employment and Relief Worker, by Sector

\begin{tabular}{|c|c|c|c|c|}
\hline \multirow[b]{2}{*}{ Variable } & \multicolumn{2}{|c|}{ Construction } & \multicolumn{2}{|c|}{ Health and Welfare } \\
\hline & Employment & $\begin{array}{l}\text { Relief } \\
\text { Workers }\end{array}$ & Employment & $\begin{array}{l}\text { Relief } \\
\text { Workers }\end{array}$ \\
\hline Relief workers (t-1) & $\begin{array}{l}-.68 \\
(.15)\end{array}$ & $\begin{array}{l}1.12 \\
(.06)\end{array}$ & $\begin{array}{l}.020 \\
(.654)\end{array}$ & $\begin{array}{l}.79 \\
(.05)\end{array}$ \\
\hline Relief workers (t-2) & $\begin{array}{c}.37 \\
(.20)\end{array}$ & $\begin{array}{l}-.71 \\
(.08)\end{array}$ & $\begin{array}{l}-.38 \\
(.85)\end{array}$ & $\begin{array}{l}-.21 \\
(.07)\end{array}$ \\
\hline Relief workers (t-3) & $\begin{array}{l}-.35 \\
(.16)\end{array}$ & $\begin{array}{c}.37 \\
(.06)\end{array}$ & $\begin{array}{l}-.72 \\
(.60)\end{array}$ & $\begin{array}{c}.04 \\
(.05)\end{array}$ \\
\hline Employment (t-1) & $\begin{array}{c}.79 \\
(.06)\end{array}$ & $\begin{array}{l}-.02 \\
(.02)\end{array}$ & $\begin{array}{l}.58 \\
(.08)\end{array}$ & $\begin{array}{l}.007 \\
(.007)\end{array}$ \\
\hline Employment (t-2) & $\begin{array}{l}-.15 \\
(.08)\end{array}$ & $\begin{array}{l}.01 \\
(.03)\end{array}$ & $\begin{array}{l}-.13 \\
(.09)\end{array}$ & $\begin{array}{l}-.009 \\
(.008)\end{array}$ \\
\hline Employment (t-3) & $\begin{array}{l}-.19 \\
(.07)\end{array}$ & $\begin{array}{c}.02 \\
(.03)\end{array}$ & $\begin{array}{c}.13 \\
(.07)\end{array}$ & $\begin{array}{l}-.005 \\
(.006)\end{array}$ \\
\hline $\begin{array}{l}\text { F-Statistic and } \\
\text { [p-value for Lagged } \\
\text { Relief Workers] }\end{array}$ & $\begin{array}{l}9.07 \\
{[.00]}\end{array}$ & $\begin{array}{r}137.68 \\
{[.00]}\end{array}$ & $\begin{array}{l}2.31 \\
(.08)\end{array}$ & $\begin{array}{r}150.02 \\
{[.00]}\end{array}$ \\
\hline $\begin{array}{l}\text { F-statistic and } \\
\text { [p-value for Lagged } \\
\text { Employmeat] }\end{array}$ & $\begin{array}{r}146.19 \\
{[.00]}\end{array}$ & $\begin{array}{c}.64 \\
{[.59]}\end{array}$ & $\begin{array}{c}28.16 \\
(.00)\end{array}$ & $\begin{array}{c}.54 \\
{[.65]}\end{array}$ \\
\hline Sample Size & 288 & 288 & 168 & 168 \\
\hline
\end{tabular}

Notes: Equations also include county dummies, year dummies, log average wage, vacancy rate and unemploymeat rate. 
rable 5: Exploration of stablilty of Beveridge Curve in Sweden County-Level Data, 1981-91

\begin{tabular}{|c|c|c|c|c|c|c|}
\hline \multirow[b]{3}{*}{ vartable } & \multicolumn{6}{|c|}{ Dependent varlable: } \\
\hline & \multicolumn{4}{|c|}{ Onemployment Rate } & \multicolumn{2}{|c|}{ UR+Programs } \\
\hline & (1) & (2) & (3) & (4) & (5) & $(6)$ \\
\hline Vacancy Rate & $\begin{array}{r}-2.34 \\
(.19)\end{array}$ & $\begin{array}{r}-1.70 \\
(.26)\end{array}$ & $\begin{array}{r}-1.83 \\
(.18)\end{array}$ & $\begin{array}{r}-1.76 \\
(.16)\end{array}$ & $\begin{array}{r}-2.07 \\
(.25)\end{array}$ & $\begin{array}{r}-2.22 \\
(.25)\end{array}$ \\
\hline Year $(+200)$ & $-\infty$ & $\begin{array}{l}-.16 \\
(.01)\end{array}$ & $-\infty$ & $\begin{array}{l}-.19 \\
(.02)\end{array}$ & $\begin{array}{l}-.22 \\
(.02)\end{array}$ & $\begin{array}{l}-.031 \\
(.03)\end{array}$ \\
\hline $\begin{array}{l}\text { Proportion } \\
\text { Public sector }\end{array}$ & $\infty$ & - & $\begin{array}{l}-.13 \\
(.02)\end{array}$ & $\begin{array}{l}.052 \\
(.025)\end{array}$ & $-\infty$ & $(.123)$ \\
\hline $\begin{array}{l}23 \text { County } \\
\text { Dumintes }\end{array}$ & Yea & Yos & Yes & Yos & $Y \bullet \boldsymbol{E}$ & Yes \\
\hline $\mathbf{R 2}$ & .69 & .80 & .74 & .82 & .80 & .81 \\
\hline sample s1ze & 264 & 264 & 264 & 264 & 264 & 264 \\
\hline
\end{tabular}

Notess Regresslon aleo Include constante. proportion public sector 10 the proportion of the labor force employed in the publlc sector. Vacancy rate 1: the number of regleterod vacancles

relative to the labor lorce. Unomployment rate is the unemployment rate derived fron the reglsters. UR+Program is (Unemployed t Rellef Horkere + Number on Tralning Programe + Number on Youth Programe)/Iabor Force. 
Table 6: Modeis for Cross-Country Differances in
onemployment, $1983-88$ and 1993 Dependent Variable: Onemployment Rate (Percent)

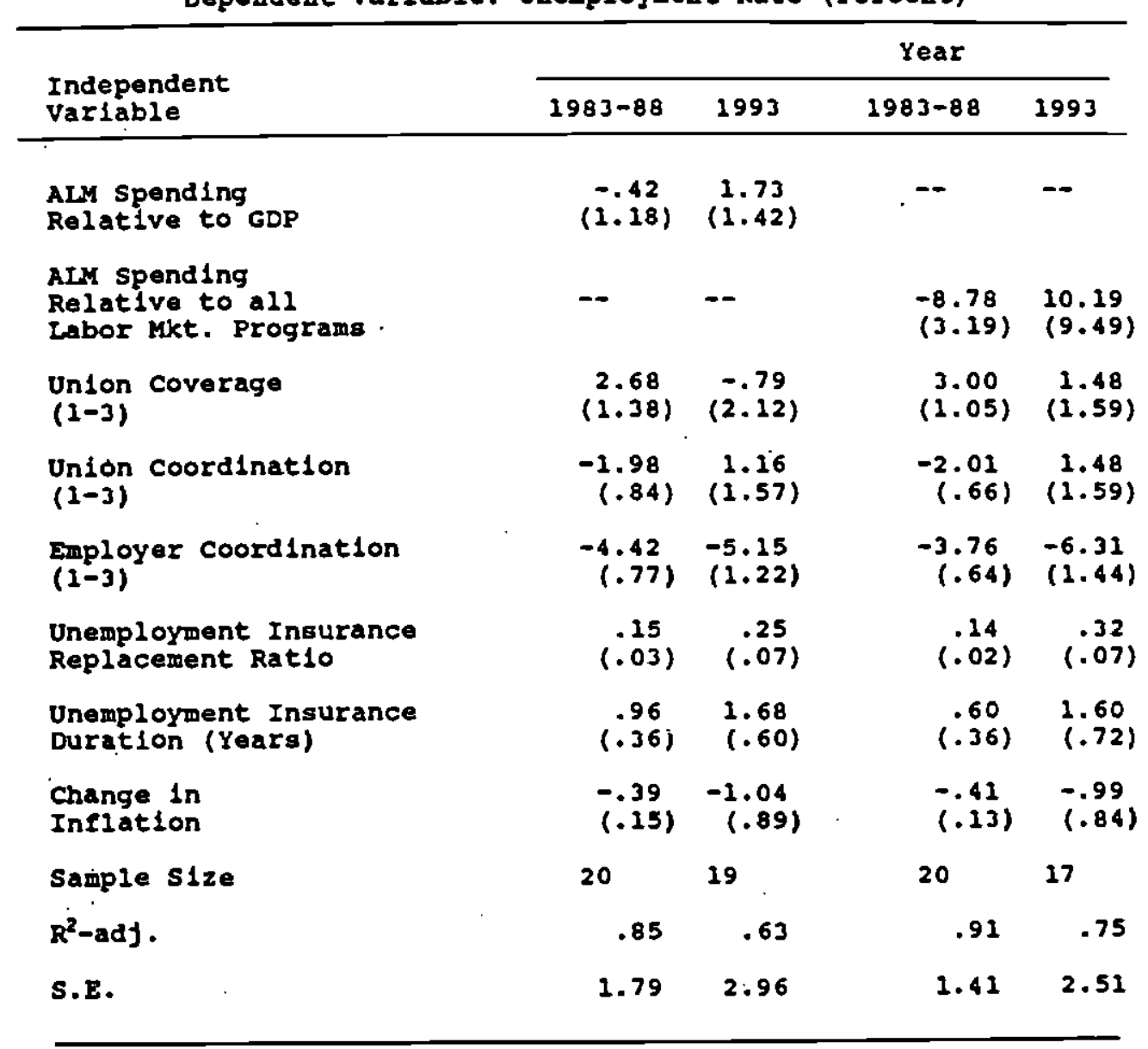

\section{Notes:}

a. Standard errors are In parentheses.

b. The ALM spending relative to GDP and ALM spending relative

to all labor market program variables pertain to 1987 in

columns (1) and (3), and avallable years between 1991 and 1993

In columns (2) and (4) (Source: OFCD Employment out look. 2993). 
Table 6 -- Continued

The change in Inflation varlable is for 1983 to 1987 in columns

(1) and (3), and to 2992 to 1993 in columns (2) and (4)

(Source: ofce Main Fconomle Inldicators). All other

explanatory variables are erom Layard, Nickell and Jackman (1992). 
Table 7: Univariate Models of Relative Employment and Unemployment Across Regions

\begin{tabular}{|c|c|c|c|c|}
\hline \multirow{2}{*}{$\begin{array}{l}\text { Coefficient on } \\
\text { lagged dependent } \\
\text { variable }\end{array}$} & \multicolumn{2}{|c|}{ U.S. } & \multicolumn{2}{|c|}{ Sweden } \\
\hline & $\begin{array}{c}\Delta \log \\
\text { Employment } \\
\text { (1) }\end{array}$ & $\begin{array}{c}\text { Unemployment } \\
\text { Rate } \\
(2)\end{array}$ & $\begin{array}{c}\Delta \log \\
\text { Employmenl } \\
\text { (3) }\end{array}$ & $\begin{array}{l}\text { Unemployment } \\
\text { Rate } \\
(4)\end{array}$ \\
\hline One lag & $\begin{array}{c}.492 \\
(.023)\end{array}$ & $\begin{array}{c}.899 \\
(.032)\end{array}$ & $\begin{array}{l}-.103 \\
(.039)\end{array}$ & $\begin{array}{l}1.020 \\
(.051)\end{array}$ \\
\hline Two lags & $\begin{array}{l}-.099 \\
(.025)\end{array}$ & $\begin{array}{l}-.159 \\
(.033)\end{array}$ & $\begin{array}{l}-.028 \\
(.038)\end{array}$ & $\begin{array}{l}-.289 \\
(.052)\end{array}$ \\
\hline Three lags & $\begin{array}{c}.010 \\
(.024)\end{array}$ & - & $\begin{array}{l}-.026 \\
(.024)\end{array}$ & 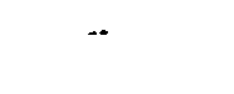 \\
\hline Four lags & $\begin{array}{l}-.054 \\
(.022)\end{array}$ & - & $\begin{array}{l}-.003 \\
(.022)\end{array}$ & -. \\
\hline$\sigma_{0}$ & .017 & .083 & .018 & .002 \\
\hline Sample period & $1952-90$ & $1972-90$ & $1981-91$ & $1978-92$ \\
\hline \multicolumn{5}{|c|}{ Implied Impulse Responses } \\
\hline $\begin{array}{l}\text { Year } 1 \\
\text { Year } 2 \\
\text { Year } 3 \\
\text { Year } 4 \\
\text { Year } 5 \\
\text { Year } 10 \\
\text { Year } 20\end{array}$ & $\begin{array}{l}1.00 \\
1.49 \\
1.63 \\
1.67 \\
1.62 \\
1.52 \\
1.53\end{array}$ & $\begin{array}{l}1.00 \\
.90 \\
.65 \\
.44 \\
.29 \\
.04 \\
.01\end{array}$ & $\begin{array}{l}1.00 \\
.90 \\
.88 \\
.86 \\
.86 \\
.86 \\
.86\end{array}$ & $\begin{array}{l}1.00 \\
1.02 \\
.75 \\
.47 \\
.26 \\
.00 \\
.00\end{array}$ \\
\hline
\end{tabular}

Note: Models include state dummies (US) or county dummies (Sweden). Columns (1) and (2) are from Blanchard and Katz (1992). Change in log employment and unemployment rate are measured relative to national levels. 